\title{
IMPLEMENTING AN EFFICIENT BEACH EROSION MONITORING SYSTEM FOR COASTAL MANAGEMENT IN CROATIA
}

Kristina Pikelj a,b *, Igor Ružić c , Suzana Ilić a , Mike R. James ${ }^{a}$, Branko Kordić ${ }^{\mathrm{d}}$

${ }^{a}$ Lancaster Environment Centre, University of Lancaster, LA1 4YQ Lancaster, UK

${ }^{b}$ Department of Geology, Faculty of Science, University of Zagreb, Horvatovac 102a,

10000 Zagreb, Croatia

${ }^{c}$ Faculty of Civil Engineering, University of Rijeka, Radmile Matejčić3, 51000 Rijeka, Croatia

${ }^{d}$ Faculty of Geodesy, University of Zagreb, Kačićeva 26, 10000 Zagreb, Croatia

*Corresponding author: K. Pikelj; e-mail address: kpikelj@geol.pmf.hr 


\title{
IMPLEMENTING AN EFFICIENT BEACH EROSION MONITORING SYSTEM FOR COASTAL MANAGEMENT IN CROATIA
}

\begin{abstract}
This paper proposes a coastal erosion monitoring system for beach erosion management, which we demonstrate on natural and artificial pocket gravel beaches in Croatia. The approach uses low-cost Structure-from-Motion (SfM) photogrammetric imaging and multi-view stereo (MVS) to produce high-resolution 3D beach models for detecting morphological changes and erosion occurrence. Coastal state indicators, such as the shoreline position and subaerial beach volume, are derived from the 3D models and used to quantify changes between surveys. The method is illustrated through two case studies and, to our knowledge, these are the first repetitive measurements taken on the Croatian eastern Adriatic Coast (CEAC). In case of the natural Brseč beach, beach rotation was found to be a response to natural forcing from waves of various incident directions. For the artificial Dugi Rat beach, which loses sediment every winter and is subsequently re-nourished every spring, monitoring showed that beach nourishment is of limited durability. Both case studies showed that the SfM-MVS technique is suitable for the rapid and frequent acquisition of 3D survey data, from which quantitative coastal indicators can be derived to inform future coastal management interventions. Significantly, this low-cost data acquisition has a great potential for regular beach management survey.

The introduction of beach monitoring in Croatia is timely because emerging Integrated Coastal Zone Management (ICZM) practices will require data-based approaches. Moreover, rare natural pocket beaches and the ever-increasing number of artificial beaches are extremely vulnerable to natural and man-made changes. Adaptive beach management, based on systematic monitoring data, should be included in the ICZM, and we detail how SfM-MVS-based monitoring can be used at different levels of the ICZM. Implementing robust ICZM monitoring will require broad considerations and consultation with all stakeholders, so we propose that SfM-MVS beach surveys should be initially integrated into the existing monitoring practices for CEAC sea water bathing quality. Extension of the existing database with rapidly-gathered low-cost $3 \mathrm{D}$ beach survey data, from a number of targeted beaches, could be used to provide a crucial baseline for the ICZM and strategic coastal monitoring of the CEAC.
\end{abstract}

Keywords: Structure-from-Motion Multi-View Stereo, gravel beach, Adriatic Sea, storms, beach erosion management, monitoring systems 


\section{Introduction}

Globally, coastlines are under pressure and, in Europe, 20\% are affected by erosion (EUROSION study, European Commission, 2004). Within this, the Croatian eastern Adriatic coast (CEAC, extending over $6000 \mathrm{~km}$ along the eastern Adriatic Sea between Slovenia and Montenegro, Fig. 1) is exposed to multiple natural and man-made pressures affecting its stability. However, the CEAC is a key area for a growing tourist market; consequently, to deliver sustainable coastal development that ensures economic activities and preserves natural beach environments, Croatian coastal management should include an evidence-based understanding of natural processes such as erosion. Here, for the first time, we apply a photo-based beach monitoring technique to deliver sequential 3D models that are suitable for informing future coastal management decision-making.

The CEAC is highly valued for its biodiversity and has an attractive rocky karst landscape that has been used intensely by humans for centuries. Both biodiversity and landscape can be impacted by the currently growing tourist demand for beach capacity, which has driven the building of artificial beaches and the enlargement of many natural beaches by nourishment, frequently carried out without suitable environmental impact studies or appropriate post-nourishment maintenance. Under increased natural pressures such as sea-level rise (SLR) (Nicholls and Cazenave, 2010), enhanced storminess (Kaniewski et al., 2016), coastal inundation due to storm surges (Međugorac et al., 2015), and unusual waves such as meteotsunamis (Šepić et al., 2012), it is likely that the CEAC coastal and beach management issues will only deepen.

At the beginning of the 21st Century, coastal development in Croatia was affected by unplanned and expanding construction, most of which was inconsistent with natural and cultural heritage (Cimerman, 2004). Currently, this is changing; Croatia is a signatory to the Barcelona Convention on environmental conservation within the Mediterranean, which includes the Protocol on Integrated Coastal Zone Management (ICZM; European Commission, 2008). The ICZM was ratified by the Croatian Government in 2012, but implementation remains in its infancy, and there is a lack of coordination among governing bodies from local to national levels and across different agencies and ministries. The responsibilities of different authorities can be unclear and can overlap and, furthermore, there is a lack of public participation in decision-making, and of public awareness about the problems that the coastline is facing. Fundamentally, progress is hampered by the complexities of the existing legal system due to the numerous different relevant laws, multiple directives for law enforcement and strategic documents related to coastal management. An integral model of coastal zone management has yet to be established. 
Likewise, there is no integrated system of beach management designed to evaluate beach environments from all aspects. Currently, Croatian beach management is the responsibility of local authorities (coastal municipalities and towns) and includes land and sea use, infrastructure development, cultural heritage preservation, allocation of concessions etc., as well as beach erosion issues. Management practices are guided by two main national documents: the Law of maritime domain and seaports (https://www.zakon.hr/download.htm?id=505) and the Regulation on Sea Bathing Water Quality (Official Gazette 73/08), with the latter shaped according to EU directive 2006/7/EC (OJEU, 2006). However, the related beach management strategies and directives are broad and services-oriented (Ministry of Tourism, 2013; PAP/RAC, 2010) and, critically, omit issues of coastal erosion. Tackling this gap, to enable appropriate adaptive policies to be developed and applied through estimating future beach changes, requires an understanding of coastal processes and their effects over local and regional scales. Beaches act as an energy buffer, contribute to coastal environmental diversity and provide recreational environments. Regardless of which of these form the primary role, a better understanding of beach origin and evolution is crucial for effective beach protection within coastal management strategies. Such an understanding is usually derived from extensive monitoring thus, as the first step in Croatia, it is essential to identify vulnerable coastal locations and to implement a suitable monitoring plan to acquire data over appropriate spatial and temporal scales.

Typically, beach monitoring comprises deriving high-resolution topographic digital elevation models (DEMs) using data from terrestrial and airborne laser scanners, multibeam sonars, differential global positioning system (dGPS), and total station surveys (Baptista et al., 2008; Casella et al., 2014; Pietro et al., 2008; White and Wang, 2003). Techniques such as satellite and video imaging can be used for detecting the shoreline position, with the latter also providing intertidal DEMs (Kroon et al., 2007). Most recently, the use of unmanned aerial vehicles (UAVs) has been explored (Brunier et al., 2016; Gonçalves and Henriques, 2015; Jaud et al., 2016). DEMs are then used to assess coastal processes and coastal morphology changes over various temporal and spatial scales (Li and King, 2007; White and Wang, 2003; Young and Ashford, 2006) and can be used to support coastal management (Davidson et al., 2007). However, for the CEAC, most satellite data have suboptimal temporal and spatial resolution, and airborne LIDAR could only be acquired occasionally due to the high cost involved, leading to inadequate temporal coverage. dGPS surveys are still used infrequently, mainly due to restricted beach access in coves between headlands, the time required for fieldwork and limited equipment availability. Video systems could provide 
valuable data at suitable temporal and spatial scales for coastal management in Croatia, but logistical difficulties, and deployment and ongoing costs have prevented their use so far.

Photogrammetric computer vision software offers an alternative and complementary surveying approach by enabling DEMs to be created from ground-based field photographs taken by a consumer-grade camera. Recently, DEMs created by using such a Structure from Motion (SfM) photogrammetry approach, combined with Multi-View Stereo (MVS), have been increasingly utilized in geosciences and engineering (e.g. James and Robson, 2012; Westoby et al., 2012), including demonstrating potential for measuring coastal changes (James and Robson, 2012; Ružić et al., 2014). Furthermore, the relatively coarse texture of the gravel beaches along the CEAC is advantageous for the SfM-MVS process, which can fail in the presence of homogenous surfaces (James and Robson, 2012; Mancini et al., 2013).

Such techniques can produce detailed topographic data but, to inform coastal management actions, the data need to be reduced to a simplified set of Coastal State Indicators (CSIs) to provide insight into the processes involved. CSIs are defined as "issue-related parameters that can simply adequately and quantitatively describe the dynamic state and evolutionary trends of a coastal system" (Davidson et al., 2007), and their identification is a combined effort between coastal scientists and end users (Van Koningsveld et al., 2005). Fundamentally, CSIs should facilitate both monitoring and assessment of environmental problems, and help identify solutions for management issues. Recently, various video-derived CSIs were tested within the European CoastView Project (Davidson et al., 2007) for use on diverse management concerns. Other CSIs, such as beach user density, shoreline contours, beach volumes, momentary coastline (MCL) positions and dune foot position, have been proved valuable in recreational beach management, to determine shoreline evolution and to identify natural development and anthropogenic impacts (Giardino et al., 2014; Jimenez et al., 2007; Kroon et al., 2007).

The aim of this paper is twofold: i) to demonstrate the use of the emerging low-cost and labourefficient Structure-from-Motion (SfM) photogrammetric approach to ascertain useful data and parameters for effective monitoring of gravel beaches along the CEAC, and ii) to use the obtained data to define appropriate CSIs for management purposes. We first describe the main natural characteristics of the CEAC and the study sites, along with their anthropogenic pressures, before describing the applied SfM-MVS survey methodology. The results of the first systematic beach monitoring in Croatia to cover event and seasonal time scales are then provided, with a description of the indicators useful for site-specific management policies. Finally, we discuss the usefulness of 
the approach and its implementation alongside existing coastal monitoring practices in Croatia for future management purposes.

\section{Study area}

\subsection{Natural settings}

The CEAC lithology is rather simple, including predominant carbonates and less represented flysch, occasionally associated with other clastics (Fig. 1). More than $90 \%$ of the eastern Adriatic coast is formed in carbonates, while approx. $6 \%$ is formed in flysch. In the case of the CEAC, this ratio is even higher in favour of carbonates. The interplay between underlying geology, tectonics, marine processes, sediment input, and variations in climate and relative sea level changes over the Quaternary and Holocene time-scales has led to the development of the intricate transgressive, steep, rugged rocky karstic coast. With coastal mountains abruptly sinking into the sea, steepness is one of the main characteristics of the CEAC, where depths of 10-20 m occur in proximity to beaches (Pikelj et al., 2009; Pikelj and Juračić, 2013). The general orientation of the coastline is NW-SE, with islands and channels running parallel to the coastline to form recognizable Dalmatianstyle coast (Fairbridge, 1968; Von Richthofen, 1901).

As a result of the carbonate lithology, sediment-starved coast and weak surf energy of the Adriatic Sea, typical coastal forms such as beaches and cliffs are relatively rare along the CEAC, occurring most often in areas of easily erodible flysch. Beaches developed in flysch are sandy and longer compared to gravel beaches formed in carbonates (Pikelj and Juračić, 2013; Pikelj et al., 2013). The majority of beach sediment in carbonate coasts comes from gravelly alluvial fans, supplied by relict or recent torrential surface flows. A high correlation between beaches and drainage area surfaces indicates that the beach sediment budget depends largely on drainage area and thus on surface flow sediment input (Benac et al., 2010). Besides surface streams, gravelly beaches are fed by material derived from rockfalls, rock debris and rock weathering (Juračić et al., 2009; Pikelj and Juračić, 2013). The sediment contribution from Croatian coastal rivers is relatively low (Juračić and Prohić, 1991; Pikelj and Juračić, 2013: Pikelj et al., 2016: Sondi et al., 1994) due to the predominant carbonate lithology.

(Figure 1)

The CEAC experiences a micro-tidal regime, with 0.2-0.5 m mean daily tidal range. The most frequent wind waves are generated by Bora (NE) and Sirocco (SE) winds. Bora waves are fetch- 
limited, of significant wave height (Hs) of $4 \mathrm{~m}$ and mean wave period (Tm) of $6 \mathrm{~s}$ in deep offshore water during the extreme events. Waves of higher significant wave height ( $\mathrm{Hs}=5-6 \mathrm{~m})$ and longer mean period (Tm up to 7-8.5 s) in deep water are generated by long-lasting Sirocco along the Adriatic (HHI, 1999). A coupled action of the Sirocco wind, seiche and tide, accompanied by low air pressure, may result in storm-surges at the CEAC's northern end, raising the sea-level by up to, and occasionally over, $1 \mathrm{~m}$ (Međugorac et al., 2015). In addition to wave generated by those two dominated winds, shore-normal waves are also generated by a rare and non-persistent wind, the Adriatic Libeccio (SW), in particular along the NW-SE oriented part of the CEAC. These rare waves are encountered during winter seasons and are accompanied by water piling up to the shore and causing strong and destructive breakers as observed elsewhere (Penzar et al., 2001; Poulain and Raichich, 2001). The magnitude and frequency of the above conditions vary with seasons, being of larger magnitude and more frequent during winter. In general, the coastline experiences lower energy from low-fetch NE waves than from SE waves. However, characteristics of the nearshore waves are largely unknown due to measurements being rare and intermittent.

\subsection{Anthropogenic pressures}

The main anthropogenic effects on the CEAC are related to tourism and associated activities (urban expansion, transport, agriculture). These activities are concentrated mostly on islands and in the narrow strip of the coastline backed by steep mountains, during summer months (Croatian Bureau of Statistics, 2017). Tourism in Croatia started to grow rapidly in the 1960s, with total overnights peaking in 1988. A decrease was recorded in 1990 due to the Homeland war but, by 2010, the numbers of tourist overnights had recovered to 1988 values and are still increasing (Croatian Bureau of Statistics, 2017). These trends are reflected in rapid coastal urbanization. According to the Report of the State of the Space from the Republic of Croatia (Ministry of Construction and Physical Planning, 2013), $150 \mathrm{~km}$ of the CEAC was urbanized prior to 1960, while this number was over fivefold higher $(837 \mathrm{~km})$ over the 1960 - 2000 period. This trend continued at the beginning of the 21 st Century, leading to $20 \%$ of the CEAC being constructed or planned for construction (Hinkel et al., 2015), while approximately the same length is estimated to be anthropogenically changed over the next 20 years (PAP/RAC Synthesis Report, 2007). Due to classic "sun and sea" tourism, Croatian beaches are still the main component of tourist resources. Rapid tourism growth is raising demand for beach capacities on the one hand, while accompanied construction is directly affecting the natural dynamic of existing beaches and coastline. In order to protect coastal properties many hard structures were built and erosion occurred where these structures interfered with natural beaches (e.g., Rab Island; Juračić et al., 2009), while an uncontrolled disposal of 
constructional waste disturbed beach dynamics, causing erosion in some places (Pikelj et al., 2013; Rajčić, et al., 2010). In order to increase recreational and bathing capacities, spaces between hard structures were used to build artificial beaches. The beachfill material used for their construction is quarried carbonate aggregate; however, many of these beaches are recently being subjected to erosion. As a solution, additional hard structures are being built for protection or larger amount of aggregate was used for the replenishment. In many of these cases, decision-making was carried out at the municipality level, by concession owner or small stakeholders, mostly with county permission and funding. A similar practice of nourishment is applied for enlarging natural beaches, causing irreversible changes and general deterioration.

\subsection{Erosional status of the CEAC}

Due to the predominant carbonate lithology, the CEAC is considered to be of low vulnerability to natural pressures and, overall, less vulnerable to sea level rise (SLR) than some other coastlines. However, the local response of particular coastal region to SLR and related impacts, depends greatly on its morphology (Barić et al., 2008; Juračić et al., 2009: Pikelj et al., 2013). Erosion and general degradation started to occur along with the intensive coastal construction related to tourism growth. Losses of beach sediment are mostly related to diminishing sources and losses to offshore due to the very steep submarine slopes. Decreases in sediment flux due to dam construction near the Cetina River mouth (middle Adriatic, Fig. 1), are resulting in an erosive effect on the local sandy beach system (Pikelj et al., 2013). In addition, regulation of torrential streams in order to prevent flooding has deprived many pocket beaches of sediment supply from their watersheds (e.g., Mošćenićka Draga in the northern Adriatic), as also observed elsewhere (Brunel and Sabatier, 2009; Pranzini and Rosas, 2007). This is particularly relevant in limestone environments where erosion rates and sediment input from hillslopes are low (Hooke, 2006). Consequently, any activity related to further reduction of sediment input along the CEAC may lead to changes in beach dynamics and eventually provoke beach erosion. Additionally, mechanical weathering of carbonate pebbles caused by frequent sediment turnover may add to beach sediment loss, as shown in the example of in situ abrasion of marble pebbles (Bertoni et al., 2012) having an abrasion rate comparable with that of limestone pebbles.

\subsection{Site descriptions}

Two demonstration beaches, representative of varied conditions and management concerns along the CEAC, were chosen for SfM-MVS monitoring. The Brseč is a $37 \mathrm{~m}$ long gravel beach, 
developed along the steep NNE-SSW-oriented eastern coast of the Istrian Peninsula (Figs. 1 and 2). The coastal zone here is steep, narrow and abuts the mountain. The beach is a typical embayed natural pocket beach, nested between two headlands and formed by the joint action of sediment supplied by a torrential surface flow and the weathering of the surrounding limestones. The mean grain size of the carbonate sediment ranges between 6 and $67 \mathrm{~mm}$; however, cobbles and boulders can occur after stormy wave conditions. Beach width may vary up to $20 \mathrm{~m}$, depending on the weather and wave conditions. These variations are accompanied by significant beach morphology and topography changes occurring on a short time scale (hours). Prevailing waves are driven by Bora (NE) and Sirocco (SE) (Section 2.1.), of which strong Bora forcing occurs more often and mostly during the winter. Such conditions also interchange with periods of strong Sirocco.

(Figure 2)

The beach has become an important natural resource for the local tourist economy since the 1970s. It is indirectly affected by coastal developments and associated land use change, mainly due to urbanisation in the lower and afforestation in the upper catchment of the watercourse that drains onto the beach. Figure 3 clearly shows the difference in land use change in the hinterland of Brseč beach. Urbanization of the area has partially sealed bedrock and natural sediment drains, leading to obstruction of sediment material to be transported by torrents. Furthermore, shrubbery coverage of the terrain has reduced direct runoff and erosion from the bare ground. Similar changes on Elba Island were reported by Nordstrom et al. (2004), which can affect beach stability over the longterm. The comparison of digitalized 1968 and 2011 photos (DGU, https://ispu.mgipu.hr/) of Brseč beach (Fig. 3C) indicates potential decadal erosion. It is estimated that the beach retreated approximately $9.5 \mathrm{~m}$, giving the average erosion rate of $0.22 \mathrm{~m} / \mathrm{y}$. A similar example was given by Pranzini and Rosas (2007). However, this rate is considered to be high for this miniature pocket beach and should be taken with caution. It should be noted that the quality of the aerial photography is quite low and the tidal elevation at acquisition was unknown.

(Figure 3)

Dugi Rat beach (Middle Dalmatia) is an $80 \mathrm{~m}$ long urban beach, oriented W-NW to E-SE, and one of three embayed artificial beaches protected by rocky groynes (Figs. 1 and 4). The current appearance of the beach is the result of decades of human activity, with this stretch of the coast being significantly changed during the 1960s when the motorway was built. The road was cut in erodible flysch and partially protected by a revetment wall, along which a concrete promenade was 
constructed during the 1980s. Further works on the beach were carried out during the 2000s; large rocks were introduced to construct groynes and also to provide a ground for the beach (Figs. 4 and 5). The beach body was built in 2008 and has been replenished annually since, in order to maintain its size despite continuous sediment loss. Cessation of industrial activities and orientation to tourism resulted in increased numbers of beach users over a relatively small period. This upward trend, which is expected to continue in the future, could lead to the beach exceeding its carrying capacity and to a need for further expansion. Due to a lack of natural sediment sources (Section 2.1.), the material used for the nourishment is crushed quarried carbonate stone aggregate of particle size 4-8 $\mathrm{mm}$ in diameter. The beach is bordered by stone groynes, and a groyne-pier in the middle (Fig 4; enlarged view) divides it into two parts, the north-western and south-western sections, denoted as DRN and DRS, respectively.

\section{Methodology}

The SfM-MVS approach is derived from advances in computer vision that facilitate photogrammetric measurement and enable low-cost, straightforward and rapid data collection with consumer-grade, uncalibrated cameras. The scene geometry, camera locations and orientation are automatically and simultaneously derived from overlapping photos taken from different positions (Brown and Lowe, 2005; Snavely et al., 2008a, 2008b; Ullman, 1979), with the results georeferenced to a real-world coordinate system through the use of ground control points (GCPs). For topographic surveying, high-resolution centimetric precision DEMs can be obtained, comparable to those obtained by laser scanning (James and Robson, 2012; Johnson et al., 2014; Westoby et al., 2012) and SfM-MVS is now used over a broad range of geoscience applications (see reviews in Bemis et al., (2014), Carrivick et al., (2016) and Eltner et al., (2015)).

For detection of beach surface change, centimetric survey precision is required. Based on the overall precision-to-viewing-distance ratio of $\sim 1: 1000$ which is achievable with SfM-MVS (James and Robson, 2012), such precision can be attained using photographs viewing over several tens of metres if appropriately distributed GCPs with high-quality dGPS-measured coordinates are available. Although survey specifics for the two case study sites given here vary slightly, the overall survey design was based on that used previously for repeated coastal cliff surveys (James and Robson, 2012), to give suitable numbers (100’s) of appropriately overlapping ( $>60 \%$ ) photographs, collected in convergent geometries and under diffuse lighting conditions (fuller descriptions of the methods are given in James and Robson (2012), James et al., (2013) and Ružić et al., (2014)). General SfM-MVS data collection recommendations can be found in many previous studies (e.g. 
Bemis et al., 2014; Gienko and Terry, 2014; James and Robson, 2012; 2014; Eltner et al., 2015; Fonstad et al., 2013; Westoby et al., 2012), but the beach environment requires some specific considerations; as much as possible, surveys were carried out at same tidal level and during low wave activity, to minimise differences in the retrievable DEMs extent and any effects of wave runup. In addition, on the CEAC, survey timing has to be particularly well organised in order to survey under diffuse light conditions because the overcast skies required are relatively rare, even during winter.

\subsection{Brseč}

The Brseč beach was monitored for three autumn and winter months in 2013 (October $4^{\text {th }}$ to December $27^{\text {th }}$ ), with an average periodicity of 10 days. During the monitoring period, several stormy events occurred, caused by waves forced by Bora (NE) and Sirocco (SE) winds. Up to 250 photographs were collected for each survey, using a single 10-megapixel Ricoh GR Digital IV camera, and taking care to acquire sharp and well-focused images under diffuse lighting conditions. Surrounding rocks enabled the photographs to be taken from a wide range of vertical and horizontal angles, and the 3D point clouds were generated using Autodesk ReCap online service (https://recap360.autodesk.com/). The ReCap service did not permit control data to be included in the processing, so the resulting point clouds were georeferenced to the HTRS96 Croatian coordinate system in CloudCompare software (http://www.danielgm.net/cc/). Georeferencing was carried out by using four Ground Control Points (GCPs) painted clearly on the rocks, which could be manually identified within the point clouds and had ground coordinates obtained by real-time kinematic GPS (RTK-GPS). Twenty-four randomly chosen 'verification points' in the beach area of the point cloud were compared with RTK-GPS survey data to give a root mean square error (RMSE) in the vertical of $3.2 \mathrm{~cm}$, which is within the magnitude of the RTK-GPS measurement precision. In order to analyse beach morphology changes, the georeferenced point clouds, with densities of up to 40000 points $/ \mathrm{m}^{2}$, were used to generate DEMs from which two coastal indicators were derived: the beach volume and the shoreline position. Subaerial beach volumes for all DEMs were calculated from different levels $(0 \mathrm{~m}, 0.25 \mathrm{~m}, 0.5 \mathrm{~m}$, and $0.75 \mathrm{~m})$ but, in order to assess volumetric changes between all surveys, only volumes from $0.5 \mathrm{~m}$ and $0.75 \mathrm{~m}$ levels are considered here. The shoreline positions were assessed at the $0.4 \mathrm{~m}$ beach contour.

\subsection{Dugi Rat}


Five surveys were carried out on the Dugi Rat beach between February $21^{\text {st }} 2015$ and June $27^{\text {th }}$ 2016. Up to 600 photographs were collected each time, using either a Canon EOS 450 D or a Canon EOS 400 D digital camera. A “walk-around” survey scheme was applied, covering the study area from a wide range of vertical and horizontal angles by holding the camera at eye level and mounted overhead on a pole. Before photograph collection, 25 fixed GCPs were marked by paint and their $3 \mathrm{D}$ coordinates were determined by virtual reference station real-time kinematic (VRS RTK) positioning, using a Trimble R8 GNSS receiver and the CROPOS VPPS service (DGU, http://www.cropos.hr/). Horizontal and vertical accuracies were within 2 and $4 \mathrm{~cm}$, respectively. Photo processing into 3D point clouds and georeferencing to the HTRS96 Croatian coordinate system were carried out using Agisoft PhotoScan Pro software. PhotoScan enables GCPs to be included directly within the processing (i.e., in the photogrammetric bundle adjustment) and the resulting RMSE on the control points varied between $13 \mathrm{~mm}$ and $57 \mathrm{~mm}$ (mostly $<30 \mathrm{~mm}$, within the magnitude of dGPS precision). The dense point clouds (up to 96000 points $/ \mathrm{m}^{2}$ ) were exported to Surfer (Golden Software) for interpolation into DEMs. In order to analyse beach morphology changes, beach volume was derived as a CSI. To quantify volumetric and geomorphic changes between surveys, sequential comparisons of successive DEMs was carried out by creating DEMs of difference (DoDs) for beach areas covered in all surveys (i.e., above $0 \mathrm{~m}$ elevation). Thus, necessarily, some lower areas of subaerial beach are omitted in the analyses. Nevertheless, observations of DEM contour position changes suggest beach width and beach elevation as potential CSIs.

\section{Results}

\subsection{Shoreline and beach volume changes on Brseč beach}

Comparison of the shorelines derived for $0.4 \mathrm{~m}$ elevation shows three broadly different conditions (Fig. 6). An approximately average state (or medium condition) was detected during the first survey (Fig. 6A), and the shoreline, marked as red, stretches uniformly along the beach, connecting two rocks on the opposite sides by an almost straight line. The first beach rotation occurred in November as the result of stormy waves $(\mathrm{Hs}=2.80 \mathrm{~m})$ generated by strong Bora $(\mathrm{NE})$. The shoreline retreated by $\sim 7.5 \mathrm{~m}$ in the north-eastern corner of the beach, which was the maximum retreat recorded during the monitoring period (Fig. 6B). The northernmost sector of the beach was heavily eroded (net sediment loss was $-73 \mathrm{~m}^{3}$; Table 1), leaving the coarsest sediment (cobbles and boulders) exposed on the surface (visible in the photo-realistic point cloud, Fig. 6B). The shoreline obtained after the last survey (blue line in Fig. 6C) shows beach rotation in the opposite direction, 
resulting from waves $(\mathrm{Hs}=1.80 \mathrm{~m})$ generated by strong Sirocco $(\mathrm{SE})$; the beach advanced in the $\mathrm{NW}$, while retreating $\sim 8 \mathrm{~m}$ in the SW, reflecting nearly complete removal in this area. The overall rotation of the $0.4 \mathrm{~m}$ contour shoreline was up to $32^{\circ}$ between measurements taken after SE and NE storms, with the pivot point located approximately in the middle of the shoreline (Fig. 6D).

Beach volume is a complementary indicator to the shoreline location and was calculated directly from dense 3D point clouds to avoid including the errors inherent in DEM interpolation. In order to compare all surveys, subaerial volumes were calculated from the elevations that were always covered: $0.5 \mathrm{~m}$ and $0.75 \mathrm{~m}$ (Table 1). Generally, volume increased $\left(+160 \mathrm{~m}^{3}\right)$ until the first storm, driven by Bora winds (12 and 18 November), when significant decreases (-86 and $-87 \mathrm{~m}^{3}$, respectively) were recorded. Volume then increased again and decreased $\left(-79 \mathrm{~m}^{3}\right)$ during the Sirocco storm ( $27^{\text {th }}$ December). Above $0.75 \mathrm{~m}$, similar increases and decreases of the beach volume were observed, except between 12 and 18 November, where some sediment exchange occurred between these upper parts of the beach.

(Figure 6)

(Table 1)

\subsection{Beach volume changes on Dugi Rat beach}

Table 2 summarizes the beach volumes determined for all Dugi Rat surveys. A small increase $(+3$ $\mathrm{m}^{3}$ ) in total beach volume was observed between the first two surveys (Table 2), which were taken over an event-based time-scale (pre- and post-storm), to analyse the effect of the three-day Sirocco storm during February 2015. This small change is not obvious by visual comparison of the DEMs (Figs. 7 and 8). However, DoDs revealed that both beach segments experienced erosion on their south-eastern sides (Figs. 9 and 10), while sediment accumulated on the north-western sides.

A 4-month interval (February to June 2015) separated the next two successive surveys, between which net sediment gain was detected on the DRS $\left(+15 \mathrm{~m}^{3}\right)$, while sediment was lost $\left(-18 \mathrm{~m}^{3}\right)$ on the DRN (Table 2), reflecting in an overall small sediment loss. Interestingly, the total analyzed beach volume of $291 \mathrm{~m}^{3}$ is identical to that determined before the Sirocco event in February 2015. The June 2015 DEMs showed that, in some places, the $0 \mathrm{~m}$ contour extended beyond the analyzed beach area (Figs. 7 and 8), indicating a larger beach width. At the same time, both DEMs (Figs. 7 and 8 ) and DoDs (Figs. 9 and 10) showed a slightly lower beach height along the promenade.

DEMs of both beach sections showed a general shoreward shift of the $0 \mathrm{~m}$ contour in January 2016, similar to the situation recorded in February 2015 (Figs. 7 and 8). DoDs of the DRN for this 
observational period showed slight erosion in the narrow strip of the lower beach and a prominent accumulation on the SE part of beach segment (Fig. 9); a similar trend was also detected on the DRS (Fig. 10). The third observation period (June 2015 to January 2016) revealed sediment loss over the analyzed beach area $\left(\sim-3 \mathrm{~m}^{3}\right)$, with most of the loss along the DRS section $\left(\sim-10 \mathrm{~m}^{3}\right)$. In contrast, the DRN section gained sediment $\left(\sim+7 \mathrm{~m}^{3}\right.$; Table 2$)$. This is evident in form of a bulge along the groyne on the $\mathrm{W}$ side of the DRN (Fig. 11A). The bulge occurs occasionally and with restricted longevity due to sediment being moved offshore (Fig. 11; central picture).

The largest overall change in volume $\left(\sim+10 \mathrm{~m}^{3}\right)$ was detected during the last observational period (January to June 2016). The volume increased $\left(\sim+12 \mathrm{~m}^{3}\right)$ on the DRS (Table 2$)$ and decreased on the DRN $\left(\sim-2 \mathrm{~m}^{3}\right)$. The seaward shift of the DRN 0 m contour (Fig. 7) detected in June 2016 was similar to that in June 2015, while for DRS, this shift was less obvious. Elevation differences over the early 2016 period showed considerable accumulation in the NW parts of both beach segments (Figs. 9 and 10).

\section{(Table 2)}

(Figure 7)

(Figure 8)

(Figure 9)

(Figure 10)

\section{Discussion}

\subsection{SfM photogrammetry in the CEAC environment}

Our case studies have shown that ground-based photography and the SfM-MVS approach can be used to produce valuable high-resolution DEMs in both natural and artificial beach environments. The equipment required is affordable, light and easily transportable, enabling fieldwork to be carried out rapidly and opportunistically before and after storms or other short events (Gonçalves and Henriques, 2015). As such, the ground-based SfM-MVS approach represents a cost-effective alternative to relatively expensive LIDAR surveys for CEAC beach environments. Over coastal extents of up to 100 s of metres, centimetric precision can be achieved by using ground control points measured with survey-grade GPS equipment (here, using RTK positioning mode with standard horizontal and vertical precisions of up to 2 and $4 \mathrm{~cm}$, respectively, Sections 3.1. and 3.2.). Although initial training of personnel is required in order to achieve high-quality SfM surveys (e.g. Glendell et al., 2017), with previously marked GCPs at Brseč and Dugi Rat beaches, surveys could 
be carried out in approximately 15 and 40 minutes respectively (as required for this research), and the photogrammetric processing is substantially automated, requiring only 5-7 hours of operator time per survey.

However, as for other techniques, there are some limitations. In regions of large tidal range, suitable time windows for image acquisition can be short, although this is not a problem for the CEAC (which has only a small tidal range). More substantially, refraction effects prevent submerged regions of the beach from being reliably measured by straightforward application of the SfM approach, which can restrict the assessment of overall sediment loss. Nevertheless, our work has shown that the high-resolution and coverage of the DEMs obtained enables successful derivation of beach state CSIs such as beach volume and shoreline position, that are needed to describe coastal morphology changes over different time scales. Beach width was indirectly used as an additional easily-extracted CSI that can be useful for designing and planning of beach nourishment and for estimating bathing capacity. Calculation of CSIs can be carried out in a broad range of postprocessing tools (including freeware).

As CEAC beaches are usually of lengths similar to those in our case studies (Pikelj and Juračić, 2013), the methodology demonstrated here is appropriate for regular coastal surveys along the CEAC. Thus, the SfM technique represents a powerful monitoring tool for assessing beach states through derived CSIs that are not easily obtained by other methods for similar costs and under typical CEAC conditions.

\subsection{Practical application for coastal management in Croatia}

The SfM-MVS methodology can be applied for both strategic and operational purposes, such as improving our understanding of coastal systems, decision-support for immediate interventions and for future coastline planning.

\subsubsection{Strategic level}

The implementation of ICZM in Croatia has only just started and requires monitoring and observational mechanisms as the first set of ICZM instruments (Article 16). Recent Croatian scientific and technical publications cover various ICZM topics such as architecture, technical sciences, traffic and transport, geodesy, civil engineering, economy, and politics (Kordej-De Villa et al., 2014), but coastal geology and geomorphology remain largely neglected. Consequently, there 
is a current lack of data on the coastline's physical characteristics to act as an effective baseline for future ICZM (Pikelj and Juračić, 2013).

Beside the examples given in this paper, the ground-based SfM methodology has been already used on the CEAC to assess cliff stability (Ružić et al., 2014), and other studies have been carried out in more complex coastal environments (Gienko and Terry, 2014; James and Robson, 2012; James et al., 2013). SfM-photogrammetry has also been successfully applied using an Unmanned Airborne Vehicle to derive DEMs of Baška Beach on Island Krk (Pikelj et al., 2017). By facilitating highquality affordable surveys, over a range of spatial and temporal scales, the SfM methodology represents a powerful means to fulfil beach coastal monitoring needs in Croatia. Such surveys can also enable timely assessments of sediment budgets and coastal vulnerability to sea level rise, flooding and erosion, as Croatia needs to develop a strategy for coastal adaptation to climate change.

The case studies here have demonstrated that monitoring can enhance our understanding of beach responses to different environmental conditions which, in turn, can inform beach management and further beach monitoring. In the Brseč beach case, sediment migration is rapid and may occur in a matter of days, through stormy waves driven by interchanging Bora and Sirocco winds. These changes are extensive, affecting the total beach volume and causing significant morphologic changes characterized by a shifting and rotation of the shoreline. Although this localized shoreline advance and retreat does not generally involve overall net loss or gain of sediment as observed elsewhere (Klein et al., 2002; Ojeda and Guillen, 2008), temporarily sediment losses (Table 1) can occur due to waves caused by the strongest winds.

The Dugi Rat beach was found to be affected by both Sirocco- and Libeccio-driven waves. The sediment relocation to the SE side of the groyne and groyne-pier (Figs. 9 and 10), which was observed immediately after the Sirocco storm in February 2015, indicates that Sirocco waves drive longshore sediment transport from SE to NW (Figs. 9, 10 and 11D). Similarly, longshore drift caused by Sirocco-driven waves can be responsible for sediment movement from the DRS to the DRN (Table 2) and can result in the shoreward movement of the $0 \mathrm{~m}$ contour (Fig. 7 and 8) detected in the third survey after 6 months (Figs. 9 and 10). During these autumn and winter months, both Bora and Sirocco winds were present but, due to the costal configuration, the largest waves are expected to be driven by the Sirocco (Fig. 11H; HHI, 2002). This is supported by a lack of significant change in the Dugi Rat beach after a severe Bora event (Pikelj et al., 2015). Hence, the 
sediment relocation and loss on the DRN and DRS respectively (Table 2) are interpreted as due to the prevailing Sirocco-driven waves.

Importantly for future beach nourishment planning, our data show that the interplay between the longshore current driven by a Sirocco wind, the groyne and the nearshore slope might be responsible for sediment loss. With the groyne protruding into water of $8 \mathrm{~m}$ depth, and with slopes of between 1:4 and 1:5, it is likely that longshore sediment transport is deflected seaward to beyond the depth of closure. Similarly, steep nearshore slopes were found to be partly responsible for nourished sediment leakage, as also identified for Nice Beach on the French Riviera (Anthony et al., 2011). In contrast, the shore-normal waves, driven by infrequent but powerful SW Libeccio wind (Section 2.1.), transport sediment onshore (Fig. 11F and G).

(Figure 11)

Both case studies revealed significant winter changes, but the different beaches might be most affected by waves from contrasting directions (i.e., due to beach location, orientation and overall shoreline geometry). As expected, although losses on the natural beach were minimal, they were significant on the man-made beach. This illustrates the importance of considering erosion and other sediment movement processes prior to beach construction, and that even basic beach monitoring can contribute to this understanding to determine a critical threshold between erosional and accretional wave power and help further understanding of beach response in different environmental conditions.

\subsubsection{Application to current coastal management in Croatia}

\subsubsection{Operational beach Management}

Monitoring is important at the operational level of beach erosion management, where it is useful to adopt a management framework. Various approaches are given in the literature (e.g. Williams and Micallef, 2009; Sutherland, 2010) and here we refer to guidelines compiled in the EU project CONSCIENCE (Sutherland, 2010). These guidelines are based on the frame of reference of Van Koningsveld and Mulder (2004) and Van Koningsveld and Lescinski (2007), and incorporate CSIs. The development of a monitoring programme and CSIs requires the definition of objectives at strategic, tactical and operational level (e.g. Sutherland, 2010). 
In case of the natural Brseč beach, a strategic objective might be preservation, while a tactical objective would be to maintain the beach width. In case of Dugi Rat, a strategic objective can be to maintain beach carrying capacity and the tactical objective would be to maintain the beach width.

Shoreline position and beach volume were shown to be suitable CSIs to describe the effects of natural forcing on the Brseč beach. However, beach width (easily derived from our obtained DEMs) would be an additional useful CSI for informing coastal managers about resilience to erosion and flooding for sudden storm events, and a valuable indicator for long-term planning (Fig. 3). For the Brseč beach, high-frequency event-focussed surveys are particularly needed because short-term events may have a greater impact on beach stability and might require an urgent response from coastal managers. In contrast, for long-term analysis it is advisable to take measurements when the beach is in a 'normal' state. Hence, data should be acquired over a range of temporal scales.

Beach volume was used as the CSI at Dugi Rat to illustrate the morphological development of this artificial beach. While the beach width CSI reflects the strategic objective of having sufficient carrying capacity, the beach volume will reflect addition and loss of material from the beach much better. Current practice consists of beach nourishment with approximately $50-70 \mathrm{~m}^{3}$ of aggregate every year (Fig. 11C). However, the sediment is lost during the cold season, as evidenced by a reduction in beach volume and in the narrowing of the beach (Figs. 7 and 8). This finding implies that the beach nourishment durability (the "...period between the time of initial emplacement of the sand and the earliest documented loss of at least $50 \%$ of the fill material..." as defined by Leonard et al., (1990)) is likely to be less than six months. According to observations made by the local authority responsible for nourishment, DRN is generally considered to be a natural accumulation area of the beach, while DRS is considered to be an erosional sector. Consequently, nourishment material is often distributed unevenly between the two parts of the beach. For example, of about 50 $\mathrm{m}^{3}$ of material placed on the beach sometime before June $2015, \sim 10 \mathrm{~m}^{3}$ was distributed on the DRN and $\sim 40 \mathrm{~m}^{3}$ on the DRS. Some of the existing sediment was also physically relocated from DRN to DRS, before placement of the new material. This practice may explain our measured net sediment gain $\left(+15 \mathrm{~m}^{3}\right)$ on the DRS and net sediment loss on the DRN $\left(-18 \mathrm{~m}^{3}\right.$; Table 2). Furthermore, the beach is subsequently flattened and widened by loaders and excavators (Figs. 11B and 11E) before being considered ready for the tourist season. The results of this widening are visible in both June 2015 DEMs (Figs. 7 and 8) showing the seaward shift of the $0 \mathrm{~m}$ contour, to outside of the analyzed beach area. Beach areas of lowered elevation on both DEMs (Figs. 7 and 8) and blue (erosion) on both DoDs (Figs. 9 and 10) are presumably the consequence of beach flattening, with accumulation zones resulting from filling of previously eroded sectors and beach widening. 
A number of factors affect the durability of beach fill, such as the environmental conditions during and/or immediately after the nourishment takes place, the location of the nourished material (e.g. surf zone or berm) and the amount of sediment placed and grain size and sources of the nourished sediment. In addition, offshore beach slopes will be important too (Anthony et al., 2011). None of these factors appear to be considered currently, and it is likely that the beach nourishment practice is based on recent historical practice and short-term practicalities rather than on quantitative evidence. Beach nourishment could be more cost-effective by developing an adaptive strategy, based on more frequent monitoring (as shown in case of Brseč) than the typical bi-annual surveys used elsewhere (Anfuso et al., 2001), and CSIs (Green and Ilić, 2009). Moreover, pre- and postnourishment surveys are strongly suggested, as well as surveys pre- and post-storm events.

\subsubsection{Implementation of monitoring}

Although SfM-based monitoring is relatively easy to use and inexpensive, implementing the method for the whole CEAC would involve further considerations, ranging over operational to strategic levels. At the operational level, one should consider following questions: Do all beaches require regular monitoring? What spatial and temporal coverage are required? Who will collect the data? Who will process the data and in what format should results be disseminated to practitioners and public? Who will store the data? Who will coordinate monitoring activities? At the strategic level, issues are related to the governance of coastal resources, funding, coordination between different governmental (vertical dimension) and sectorial levels (horizontal dimension), and the way monitoring is implemented e.g. by incentives for practicing data-based management or by forced regulations and penalties. As monitoring will support the ICZM, it is inevitable that the monitoring itself will require integration over different level of governments, over different sectors, different disciplines and will cover different environments e.g. coastal and terrestrial beach. The ultimate beneficiary of the ICZM and monitoring will be the general public and they should be directly involved, or involved through the local authorities with responsibilities for beach management. The method developed here is based on the relatively straightforward collection of photographs, which can also be useful to inform the public about changes taking place on the coast. This should facilitate public involvement in data collection and decision-making. Many local authorities are very small and understaffed, and they might not be able to carry monitoring activities and data processing by themselves; leaving coordination of the whole monitoring process to local authorities might lead to fragmentation rather than integration. Hence, it is likely that a new agency or a department within existing governmental agencies will need to be established to organize activities. 
This will be overseen by a committee whose members should be representatives from local authorities, governmental agencies from different sectors (e.g. tourism, transport, urban planning) and scientific institutions. The committee should ensure that needs from different local authorities are incorporated in strategic objectives, that decisions are science-based and, in return, that data are used for enhancing our system-understanding and that there is coordination in data collection between sectors.

Implementing this comprehensive monitoring framework will be challenging and will take some time, in particular during consultation processes. Thus, here, we propose an intermediate step to enable initial surveying to be instigated relatively quickly by integrating the SfM method into existing monitoring practice.

In total, 956 bathing areas are already monitored for water quality along the CEAC, by the legal representatives of seven coastal counties, coordinated by the Ministry of Environment and Energy. Together with water quality, each bathing area is associated with additional information in the form of a Beach profile - a sort of beach "ID card" of data relevant for beachgoers, but which lacks the detailed information on physical attributes that is essential for sustainable management. Recently, Ivanković and Pikelj (2017) proposed a profile update for all monitored bathing areas to include the data required for BARE analysis (Williams and Micallef, 2009). A pilot project of 32 selected beaches among all bathing areas was conducted in 2009 and showed that the majority fell into the conflict zone between conservation potential and development potential (PAP/RAC, 2010). Ivanković and Pikelj (2017) also suggested that the information collected on beach sediment characteristics, beach erosion, and beach deposition should exceed that required for BARE analysis. Initial analysis of such sediment data should be used to identify potential erosion hot spots that can then be targeted for early SfM surveying and subsequent routine monitoring as demonstrated in our case studies.

Another advantage of SfM-survey integration with water quality monitoring is that a system for the public dissemination of results is already in place. Water quality data are publicly available in a national database maintained by the Institute of Oceanography and Fisheries (http://www.izor.hr/kakvoca/). The web portal allows the public to leave comments, give suggestions and provide additional information, which can all used to improve the monitoring further. Joint work, good coordination, and efficient communication between national and regional levels are maintained through annual meetings. 
Our proposed integration of SfM-photogrammetry into the already well-established existing scheme of organized monitoring is a cost-effective way to focus effort on endangered beaches. It also drives further collaboration, exchanges of opinions and information-sharing among all parties involved. Moreover, further development and maintenance of the integrated database, accessible to the public, should raise public awareness and increase public participation in decision-making, which is ultimately of great benefit for coastal and beach management in the future.

\section{Conclusions}

Through the first systematic 3D surveys of a natural and an artificial beach, we have demonstrated that SfM-MVS photogrammetry provides a practical solution for long-term beach monitoring on the CEAC. Analysis of DEMs obtained from time-series 3D point clouds allowed the extraction of CSIs such as beach volume, shoreline position and beach width, which revealed the spatial and temporal dynamics of these beaches. The natural beach at Brseč responds rapidly to waves generated by prevailing north-easterly and south-easterly winds, changing its rotation and generating sediment losses and gains. The waves driven by the highest recorded wind speeds from the north-east caused the largest sediment loss. The surveys of the artificial beach at Dugi Rat showed that the dominant sediment transport on the monitored beach face is longshore, in a northwesterly direction, driven by Sirocco wind. Importantly, surveys revealed continuous sediment loss over 1.5 years of monitoring, despite beach re-nourishment on two occasions. The information collected by the methods demonstrated here will facilitate more effective planning of beach nourishment projects.

Due to the growing coastal development, there is an urgent need for systematic monitoring of natural and artificial beaches on the CEAC, to inform beach management and coastal strategies, and to contribute to the ICZM in Croatia which is currently still in its infancy. A comprehensive monitoring framework will require further considerations, but some existing strategies and directives related to beach management, such as sea bathing area water quality monitoring, are being implemented and an interactive database has been established. The extension of this database to include physical beach attributes could help identify erosional hot spots. Once recognized, implementation of the SfM-photogrammetry approach tested here is seen as an inexpensive way to increase our knowledge and understanding of how natural and artificial beaches respond to environmental conditions. Moreover, through the application of this technique at a number of targeted beaches, a systematic monitoring database could be further expanded to support the ICZM of the CEAC. 
This work was supported by the RAGBICOM project within NEWFELPRO programme funded by Croatian Ministry of Science, Education and Sport and the Marie Curie FP7-PEOPLE-2011COFUND and by the University of Rijeka (Croatia) through the project GEOLOGICAL HAZARD IN THE KVARNER AREA. The authors would like to thank to Dugi Rat stakeholders for supplying some of the data used in this study. We also thank Robert Košćal for help in figure preparation, while Mirela Pešut and Tourist Board of Dugi Rat are acknowledged for providing us photographs (Fig. 11F/11G and Fig. 5B, respectively). Nicola Wylie and Tina Tominić are acknowledged for help with grain size measurements, while Stipe Muslim provided technical support during Dugi Rat surveys. Logistic support during surveys in Dugi Rat was kindly provided by families Pešut and Raljević.

\section{Contributions and conflict of interest}

All authors have approved the final article and declared no conflict of interest.

\section{References}

Anfuso, G., Benavente, J., Gracia, F.J., 2001. Morphodynamic responses of nourished beaches in SW Spain. J.Coastal Conserv. 7, 71-80. http://dx.doi.org/10.1007/BF02742469

Anthony, E.J., Cohen, O., Sabatier, F., 2011. Chronic offshore loss of nourishment on Nice beach, French Riviera: A case of over-nourishment of a steep beach? Coast. Eng. 58, 374-383. http://dx.doi.org/10.1016/j.coastaleng.2010.11.001

Baptista, P., Bastos, L., Bernardes, C., Cunha, T., Dias, J., 2008. Monitoring Sandy Shores Morphologies by DGPS - A Practical Tool to Generate Digital Elevation Models. J.Coastal Res. 24 (6), 1516-31528. http://dx.doi.org/10.2112/07-0861.1

Barić, A, Grbec, B., Bogner, D., 2008. Potential Implications of Sea-Level Rise for Croatia. J.Coastal Res. 24 (2), 299-305. http://dx.doi.org/10.2112/07A-0004.1

Bemis, S.P., Micklethwaite, S., Turner, D., James, M.R., Akciz, S., Thiele, S.T., Bangash, H.A., 2014. Ground-based and UAV-based photogrammetry: A multi-scale, high resolution mapping tool 
for structural geology and paleoseismology. J. Struct. Geol. 69,163-178. http://dx.doi.org/10.2110/jsr.2017.5

Benac, Č., Ružić, I., Ilić, S., 2010. Morphodynamics of pocket beaches (Kvarner, NE Adriatic Sea) [in Croatian], in: Horvat, M. (Ed.), Abstracts Book, 4th Croatian Geological Congress, Šibenik, 2010, 384-385.

Bertoni, D., Sarti, G., Benelli, G., Pozzebon, A., 2012. In situ abrasion of marked pebbles on two coarse-clastic beaches (Marina di Pisa, Italy). Ital. J. Geosci. 131 (2), 205-214. http://dx.doi.org/10.3301/IJG.2012.04

Brown, M., Lowe, D. G., 2005. Unsupervised 3D object recognition and reconstruction in unordered datasets. 5th International Conference on 3D Digital Imaging and Modeling, IEEE Comput. Soc., Ottawa, Ontario, Canada. http://dx.doi.org/10.1109/3DIM.2005.81

Brunel, C., Sabatier, F., 2009. Potential influence of sea-level rise in controlling shoreline position on the French Mediterranean coast. Geomorphology 107, 47-57. http://dx.doi.org/10.1016/j.geomorph.2007.05.024

Brunier G., Fleury J., Anthony E.J., Gardel A., Dussouillez P., 2016. Close-range airborne Structure-from-Motion Photogrammetry for high-resolution beach morphometric surveys: Examples from an embayed rotating beach. Geomorphology, 161, 76-88.

http://dx.doi.org/10.1016/j.geomorph.2016.02.025

Carrivick, J.L., Smith, M.W., Quincey, D.J., 2016. Structure from Motion in the Geosciences. Wiley-Blackwell, 208 p. http://dx.doi.org/10.1002/9781118895818

Casella, E., Rovere, A., Pedroncini, A., Mucerino, L., Casella, M., Cusati, A., Vacchi, M., Ferrari, M., Firpo, M., 2014. Study of wave runup using numerical models and low-altitude aerial photogrammetry: A tool for coastal management. Estuar Coast Shelf Sci., 149, 160-167. https://doi.org/10.1016/j.ecss.2014.08.012

Cimerman, R., 2004. Coastal area of the Croatian Adriatic: urbanisation and planning [in Croatian]. Čovjek i prostor 51(9-10), 98-100. 
Croatian Bureau of Statistics (2017). First release, tourist arrivals and overnight stays in rented accommodation, 2016. https://www.dzs.hr/default.htm (accessed 15 Sept 2017)

Davidson, M., Van Konigsveld, M., de Kruif, A., Rawson, J., Holman, R., Lamberti, A., Medina, R., Kroon, A., Aarninkof, S., 2007. The CoastView project: Developing video-derived Coastal State Indicators in support of coastal zone management. Coastal Engineering 54, 463-475. http://dx.doi.org/10.1016/j.coastaleng.2007.01.007

Eltner, A., Kaiser, A., Castillo, C., Rock, G., Neugirg, F., Abellan, A., 2015. Image-based surface reconstruction in geomorphometry - merits, limits and developments of a promising tool for geoscientists. Earth Surf. Dynam. Discuss., 3, 1445-1508. http://dx.doi.org/ 10.5194/esurfd-3-14452015

European Commission (2008). Protocol on on Integrated Coastal Zone Management. http://eurlex.europa.eu/legal-content/EN/TXT/?uri=CELEX:22009A0204\%2801\%29 (accessed 20 Sept 2017)

Fairbridge, R.W. (Ed.), 1968. The Encyclopedia of Geomorphology. New York, Reinhold Book, $1295 \mathrm{p}$.

Fonstad, M.A., Dietrich, J.T., Brittany, C.C., Jensen, J.L., Carbonneau, P.E., 2013. Topographic structure from motion: a new development in photogrammetric measurement. Earth Surf. Process. Landforms 38, 421-430. http://dx.doi.org/10.1002/esp.3366

Giardino, A., Santinelli, G., Vuil, V. 2014. Coastal state indicators to assess the morphological development of the Holland coast due to natural and anthropogenic pressure factors. Ocean Coast. Manage. 87, 93-101. http://dx.doi.org/10.1016/j.ocecoaman.2013.09.015

Glendell, M., McShane, G., Farrow, L., James, M.R., Quinton, J., Anderson, K., Evans, M., Benaud, P., Rawlins, B., Morgan, D., Jones, L., Kirkham, M., DeBell, L., Quine, T.A., Lark, M., Rickson, J., Brayier, R., 2017. Testing the utility of structure-from-motion photogrammetry reconstructions using small unmanned aerial vehicles and ground photography to estimate the extent of upland soil erosion. Earth Surf. Processes Landforms 42 (12), 1860-1871. http://dx.doi.org/10.1002/esp.4142 
Gienko, G.A, Terry, J.P., 2014. Three-dimensional modeling of coastal boulders using multi-view image measurements. Earth Surf. Process. Landforms 39, 853-864. http://dx.doi.org/10.1002/esp.3485

Gonçalves, J.A., Henriques, R., 2015. UAV photogrammetry for topographic monitoring of coastal area. ISPRS J. Photogram. Rem. Sens. 104, 101-11. http://dx.doi.org/10.1016/j.isprsjprs.2015.02.009

Green, C., Ilić, S., 2009. The application of Argus video monitoring for assessing the impact of coastal structures on beaches. Proceedings 44th into. Conf. On flood risk and coastal management, The International Centre, Telford, 30 June to 2 July 2009, EA/DEFRA.

HHI, 1999. Nautical pilot I. Adriatic Sea Eastern coast [in Croatian], Hydrographic Institute of the Republic of Croatia, Split, 331 pp.+D 32.

HHI, 2002. Pilot for small boats. II. part [in Croatian], Hydrographic Institute of the Republic of Croatia, Split, 269 p.

Hinkel J., Vafeidis A. T., Lincke, D., Wolf, C., 2015. Assessment of Costs of Sea-Level Rise in Republic of Croatia Including Costs and Benefits of Adaptation. Integration of climatic variability and change into national strategies to implement the ICZM Protocol in the Mediterranean: National level assessments for Croatia.

Hooke, J.M., 2006. Human impacts on fluvial systems in the Mediterranean region. Geomorphology,79, 311-335. http://dx.doi.org/10.1016/j.geomorph.2006.06.036

Ivanković, D., Pikelj, K. 2017. Extension of monitoring of the Sea bathing water quality in Croatia (EU directive 2006/7/EC) - importance of beach sediment characteristics. Revue Paralia. 4 (2017) (accepted to be presented; in press).

James, M. R., Robson, S., 2012. Straightforward reconstruction of 3D surfaces and topography with a camera: accuracy and geoscience application. J. Geophys. Res.117, F03017. http://dx.doi.org/10.1029/2011JF002289 
James, M. R., Robson, S., 2014. Mitigating systematic error in topographic models derived from UAV and ground-based image networks. Earth Surf. Proc. Landforms 39, 1413-1420. http://dx.doi.org/10.1002/esp.3609

James, M.R., Ilić, S., Ružić, I., 2013. Measuring 3D coastal change with a digital camera, in: Bonneton, P., Garlan, T., Sottolichio, A., Castelle, B. (Eds): Proc. 7th Int. Conf. Coastal. Dynamics 2013, 24-28 June 2013, Arcachon. Bordeaux University, SHOM, pp 893-904.

Jaud, M., Grasso, F., Le Dantec, N., Verney, R., Delacourt, C., Amman, J., Deloffre, J., Grandjean, P., 2016. Potential of UAVs for Monitoring Mudflat Morphodynamics (Application to the Seine Estuary, France). ISPRS Int. J. Geo-Inf. 5(4), 50 http://dx.doi.org/10.3390/ijgi5040050

Jiménez, J.A., Osorio, A., Marino-Tapia, I., Davidson, M., Medina, R., Kroon, A., Archetti, R., Ciavola, P., Aarnikhof, S.G.J., 2007. Beach recreation planning using video-derived coastal state indicators. J. Coast. Eng. 54, 507-521. http://dx.doi.org/10.1016/j.coastaleng.2007.01.012

Johnson, K., Nissen, E., Saripalli, S., Arrowsmith, J.R., McGarey, P., Scharer, K., Williams, P., Blisniuk, L., 2014. Rapid mapping of ultrafine fault zone topography with structure from motion. Geosphere 10 (5), 1-18; http://dx.doi.org/10.1130/GES01017.1

Juračić, M., Prohić, E., 1991. Mineralogy, sources of particles and sedimentation in the Krka River estuary (Croatia). Geološki Vjesnik 44, 195-200.

Juračić, M., Benac, Č., Pikelj, K., Ilić, S., 2009. Comparison of the vulnerability of limestone (karst) and siliciclastic coasts (example from the Kvarner area, NE Adriatic, Croatia). Geomorphology 107(1-2), 90-99. http://dx.doi.org/10.1016/j.geomorph.2007.05.020

Kaniewski, D., Marriner, N., Morhange, C., Faivre, S., Otto, T., Van Campo, E., 2016. Solar pacing of storm surges, coastal flooding and agricultural losses in the Central Mediterranean. Sci. Rep. 6/25197, 1-12. http://dx.doi.org/10.1038/srep25197

Klein, A.H.F., Filho, L.B., Schumacher, D.H., 2002. Short-term beach rotation processes in distinct headland bay beach systems. J.Coastal Res. 18, 442-458. 
Kordej-De Villa, Ž., Rašić Bakarić, I., Starc, N. 2014. Coastal zone management in Croatia. [in Croatian]. Druš. Istraž. 3, 449-468. http://dx.doi.org/10.5559/di.23.3.04

Kroon, A., Davidson, M.A., Aarninkhof, S.G.J., Archetti, R., Armaroli, C., Gonzalez, M., Medri, S., Osorio, A., Aagaard, T., Holman, R.A., Spanhoff, R., 2007. Application of remote sensing video systems to coastline management problems. J. Coast. Eng. 54, 493-505.

Leonard, L.A., Clayton, T., and Pilkey, O.H., 1990. An analysis of beach design parameters on U.S. East Coast barrier islands. J. Coastal Res. 6 (1) 15-36.

Li, M.Z., King, E.L., 2007. Multibeam bathymetric investigations of sand ridges and association bedforms and their relation to storm processes, Sable Bank, Scotian Shelf. Mar. Geol. 243, 200-28. http://dx.doi.org/10.1016/j.margeo.2007.05.004

Mancini, F., Dubbini, M., Gatelli, M., Stecchi, F., Fabbri, S., Gabbianelli, G., 2013. Using Unmanned Aerial Vehicles (UAV) for high-resolution reconstruction of topography: The Structure from Motion approach on coastal environments. Remote Sens. 5, 6680-6898. http://dx.doi.org/10.3390/rs5126880

Međugorac, I., Pasarić, M., Orlić, M., 2015. Severe flooding along the eastern Adriatic coast: the case of 1 December 2008. Ocean Dyn. 65(6), 817-830. http://dx.doi.org/10.1007/s10236-015-08359

Ministry of Construction and Physical Planning (2013): Izvješće o stanju u prostoru Republike Hrvatske 2008. - 2012. Official Gazette of the Republic of Croatia 61/2013.

https://narodnenovine.nn.hr/clanci/sluzbeni/2013_05_61_1240.html (accessed 15 Sept 2017).

Ministry of Tourism (2013): Croatian Tourism Development Strategy until 2020. Official Gazzete of the Republic of Croatia 55/2013

https://narodnenovine.nn.hr/clanci/sluzbeni/2013 0555 1119.html (accessed 21 Sept 2017).

Nicholls, R. J., Cazenave, A., 2010. Sea-level rise and its impact on coastal zones. Science 328, 1517-1520. http://dx.doi.org/10.1038/srep25197 
Nordstrom, K.F., Jackson, N.L., Pranzini, E., 2004. Beach sediment alteration by natural processes and human actions: Elba Island, Italy. Ann. Assoc. Am. Geogr. 94, 794-806. http://dx.doi.org/10.1111/j.1467-8306.2004.00435.x

Ojeda, E., Guillén, J., 2008. Shoreline dynamics and beach rotation of artificial embayed beaches. Mar. Geol. 253, 51-62. http://dx.doi.org/10.1016/j.margeo.2008.03.010

OJEU. (2006). Directive 2006/7/EC of the European Parliament and of the Council of 15 February 2006 concerning the management of bathing water quality and repealing Directive 76/160/EEC. Official Journal of the European Union, Document 32006L0007, L 64/37. http://data.europa.eu/eli/dir/2006/7/oj

PAP/RAC Synthesis report, 2007. State of the art of coastal and maritime planning in the Adriatic region. INTERREG IIIB CADSES PlanCoast project.

PAP/RAC (2010). Sustainable beach management in Croatia - Guidelines and priority actions [in Croatian]. United Nations Development Programme in Croatia.

Penzar, B., Penzar, I., Orlić, M., 2001. Weather and climate of the Croatian Adriatic [in Croatian]. Croatian Hydrographic Institute Split, Zagreb, 257 p.

Pietro, L.S., O’Neil, M.A., Puleo, J.A., 2008. Developing Terrestrial-LIDAR-Based Digital Elevation Models for Monitoring Beach Nourishment Performance. J.Coastal Res. 24 (6), 15551564. http://dx.doi.org/ 10.2112/07-0904.1

Pikelj, K., Žigić, V., Juračić, M., 2009. Origin and distribution of surface sediments in the Grgur Channel, Adriatic Sea, Croatia. Geol. Croat. 62(2), 95-105. http://dx.doi.org/10.4154/GC.2009.08

Pikelj, K., Juračić, M., 2013. Eastern Adriatic Coast (EAC): Geomorphology and coastal vulnerability of a Karstic Coast. J. Coastal Res. 29(4), 944-957. http://dx.doi.org/10.2112/JCOASTRES-D-12-00136.1.

Pikelj, K., Dragnić, V., Malovrazić, N., 2013. Eastern Adriatic: Slovenia, Croatia and Montenegro, in Pranzini, E., Williams, A.T. (Eds.), Coastal Erosion and Protection in Europe. Oxford, UK: Routledge, Taylor and Francis, pp 324-344. 
Pikelj, K., Ilić, S., James, M.R., Kordić, B., 2015. Application of SfM photogrammetry for morphological changes on gravel beaches: Dugi Rat case study (Croatia). Revue Paralia. 3 (2015), 67-72. http://dx.doi.org/10.5150/cmcm.2015.014

Pikelj, K., Jakšić, L., Aščić, L., Juračić, M., 2016. Characterization of the fine-grained fraction in the surface sediment of the eastern Adriatic channel areas. Acta. Adriat. (57)2, 195-208.

Pikelj, K., Ružić, I., James, M., R. Ilić, S., 2017. Structure-from-Motion (SfM) monitoring of nourished gravel beaches in Croatia. COASTS, MARINE STRUCTURES AND BREAKWATERS 2017 - The leading international conference highlighting global marine engineering advances. 112:1-112:4. http://www.ice-conferences.com/coasts,-marine-structures-and-breakwaters-2017

Poulain, P.M., Raichich, F., 2001. Forcings, in: Cushman-Roisin, B., Gačić, M., Poulain, P.-M., Artegiani, A. (Eds.), Physical Oceanography of the Adriatic Sea: Past, Present and Future. Kluwer Academic Publishers, Dordrecht, pp. 45-65.

Pranzini, E., Rosas, V., 2007. Pocket beach response to high magnitude-low frequency floods (Elba Island, Italy). J. Coastal Res 50, 969-977.

Rajčić, S. T., Faivre, S. N. Buzjak, 2010. The changes in beaches surfaces in the Medići and Mimice area from 1960 till today. [in Croatian]. Hrvatski geografski glasnik, 72/2, 27-48. http://hrcak.srce.hr/64969

Ružić, I., Marović, I., Benac, Č., Ilić, S., 2014. Coastal cliff geometry derived from structure-frommotion photogrammetry at Stara Baška, Krk Island, Croatia. Geo-Mar. Lett. 34, 555-565, http://dx.doi.org/10.1007/s00367-014-0380-4

Snavely, N., Seitz, S.M., Szeliski. R., 2008a. Modeling the world from internet photo collections. Int. J. Comput. Vis. 80, 189-210, http://dx.doi.org/10.1007/s11263-007-0107-3

Snavely, N., Garg, R., Seitz, S.M., Szeliski, R., 2008b. Finding paths through the World's photos. ACM Trans. Graph., 27, 11-21, http://dx.doi.org/10.1145/1360612.1360614 
Sondi, I., Juračić, M., Pravdić, V., 1994: Sedimentation in a disequilibrium rive-dominated estuary: the Raša River estuary (Adriatic Sea, Croatia). Sedimentology 42, 769-783. http://dx.doi.org/10.1111/j.1365-3091.1995.tb00408.x

Sutherland, J. 2010. Guidelines on Beach Monitoring for Coastal Erosion, CONSCIENCE (Concepts and Science for Coastal Erosion Management, EC Contract 044122. www.conscienceeu.net (accessed 31 Oct 2017)

Šepić, J., Vilibić, I., Strelec Mahović, N., 2012. Northern Adriatic meteorological tsunamis: Observations, link to the atmosphere and predictability. J. Geophys. Res. 117, C02002, http://dx.doi.org/10.1029/2011JC007608

Ullman, S., 1979. The interpretation of structure from motion. Proc. R. Soc. London, Ser. B, 203, 405-426, http://dx.doi.org/10.1098/rspb.1979.0006

Van Koningsveld, M., Mulder, J.P.M. 2004. Sustainable coastal policy developments in the Netherlands. A systematic approach revealed. J. Coastal Res., 20 (2) 375-385. http://www.jstor.org/stable/4299296

Van Koningsveld, M., Lescinski, J. 2007. Decadal scale performance of coastal maintenance in the Netherlands. Shore and Beach, 75(1) $1-17$.

Van Koningsveld, M., Davidson, M.A., Huntley, D.A., 2005. Matching science with coastal management needs; the search for appropriate coastal state indicators. J. Coast. Res. 21 (3), 399411. http://dx.doi.org/10.2112/03-0076.1

Von Richthofen, F., 1901. Fuhrer für Forschungreisende. Hannover, Germany, Verlag Von Gebrudek Janecke, 734 p.

Westoby, M.J, Brasington, J., Glasser, N.F., Hambrey, M.J., Reynolds, J.M., 2012. "Structurefrom-Motion" photogrammetry: a low-cost, effective tool for geoscience applications. Geomorphology 179, 300-314. http://dx.doi.org/10.1016/j.geomorph.2012.08.021 
White, S.A., Wang, Y., 2003. Utilizing DEMS derived from LIDAR data to analyze morphologic change in the North Carolina coastline. Remote Sens. Environ. 85, 39-47. http://dx.doi.org/10.1016/S0034-4257(02)00185-2

Williams A.T., Micallef A., 2009. Beach Management: Principles and Practices, Earthscan Ed., London, $445 \mathrm{p}$.

Young, A.P., Ashford, S.A., 2006. Application of airborne LIDAR for seacliff volumetric change and beach-sediment budget contributions. J. Coastal Res. 22(2), 307-318.

Web references:

Autodesk ReCap online service, https://recap360.autodesk.com/ (accessed 30 May 2015)

Cloud Compare software, http://www.danielgm.net/cc/ (accessed 30 May 2015)

DGU, https://ispu.mgipu.hr/ (accessed 10 Nov2017)

DGU, http://www.cropos.hr/ (acassed 03.02.15)

Law of maritime domain and seaports (Official Gazete 158/03, 100/04, 38/09, 123/11, 56/16), https://www.zakon.hr/download.htm?id=505 (accessed 10 Sept. 2014)

Regulation on Sea Bathing Water Quality (Official Gazette 73/08), https://narodnenovine.nn.hr/clanci/sluzbeni/2008 $06 \quad 73$ 2426.html (accessed 10 Sept.2014) 


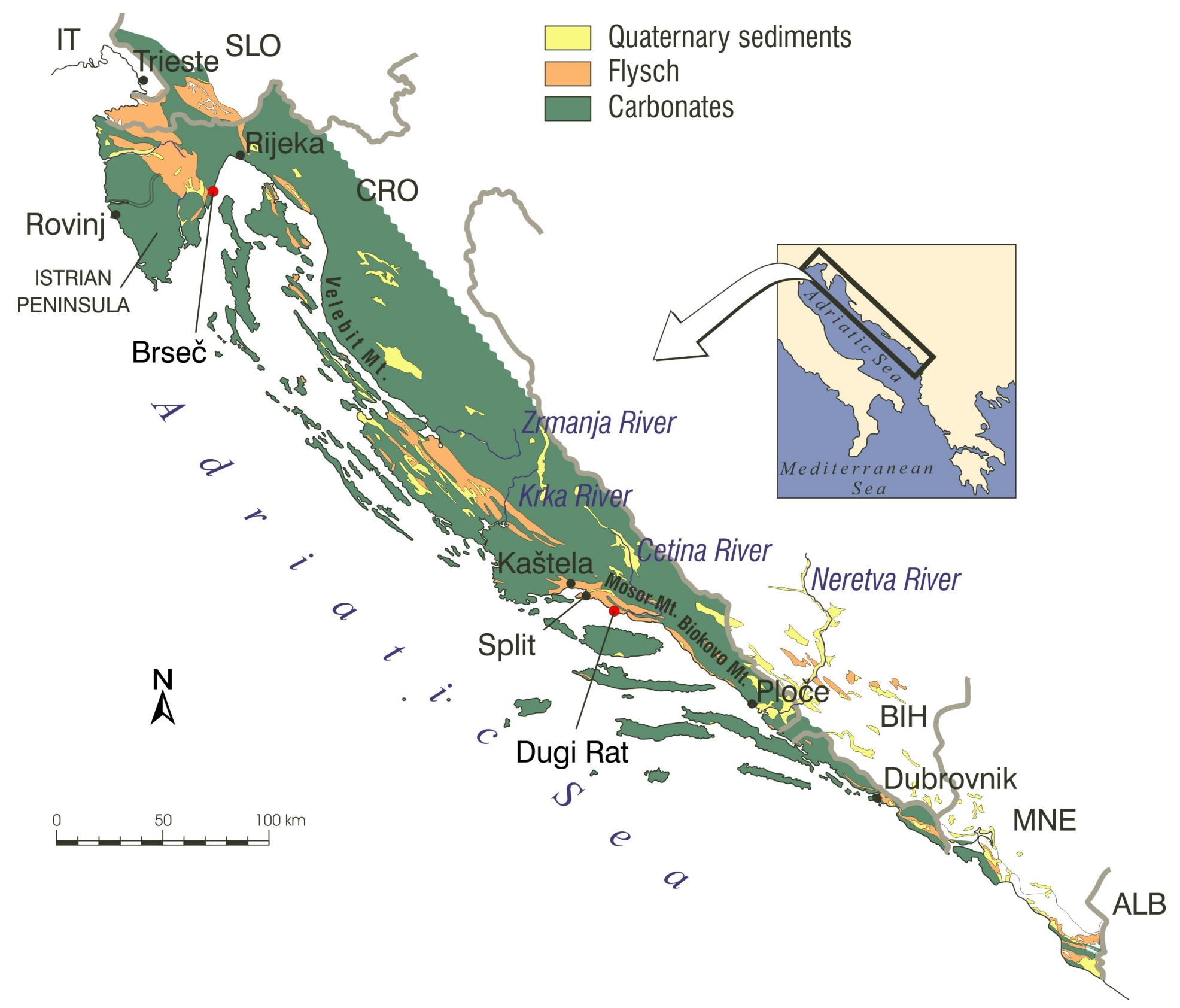




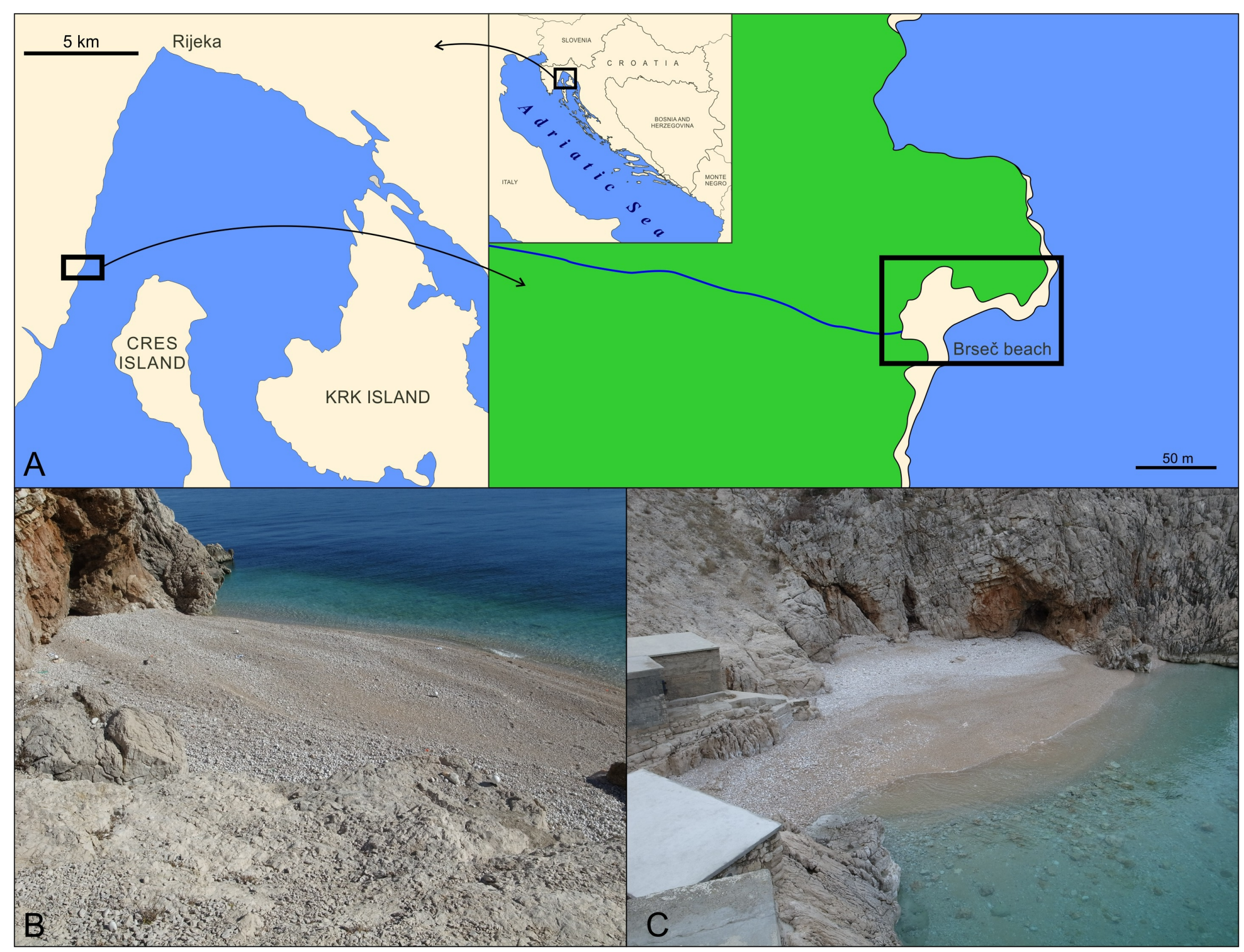




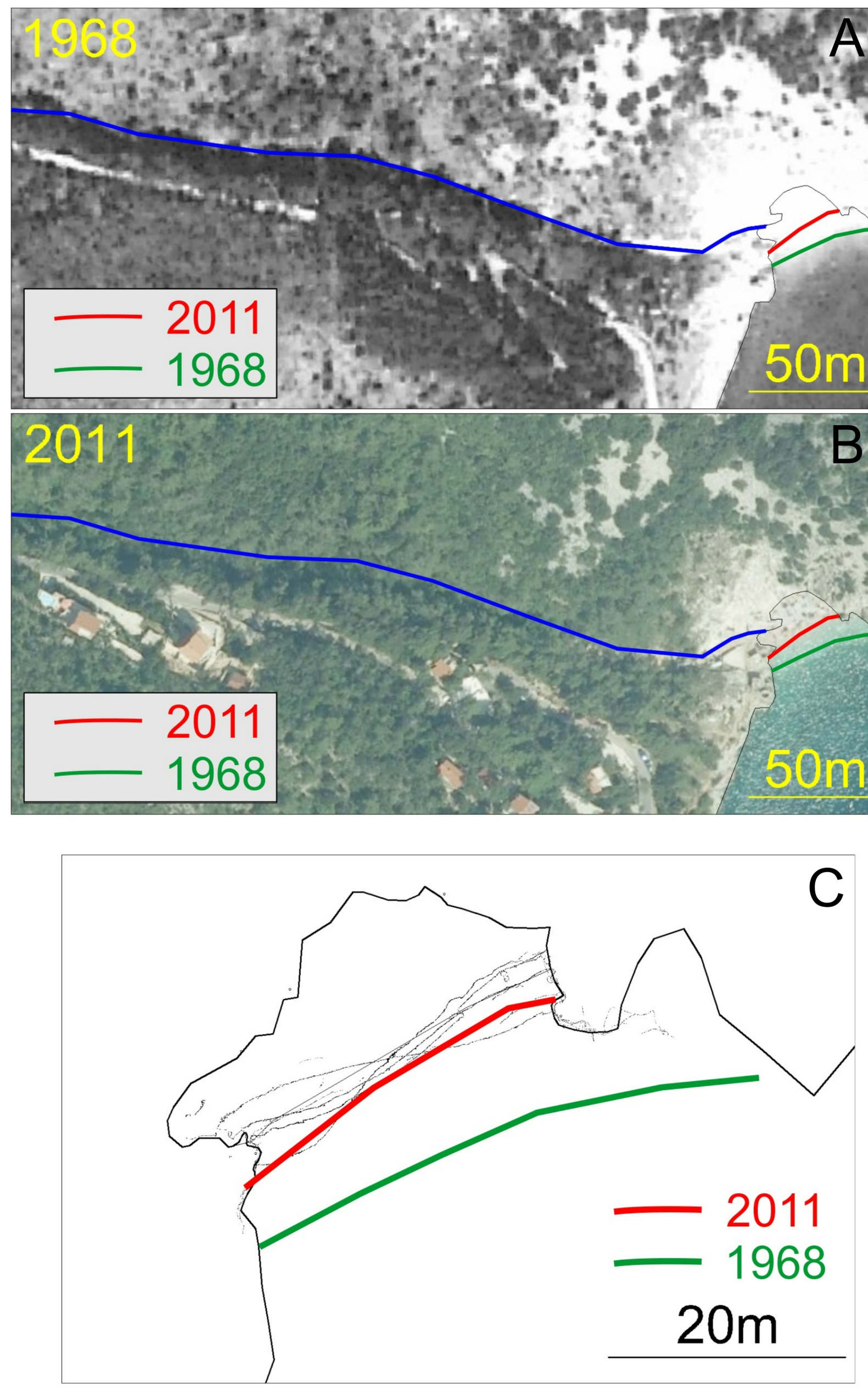




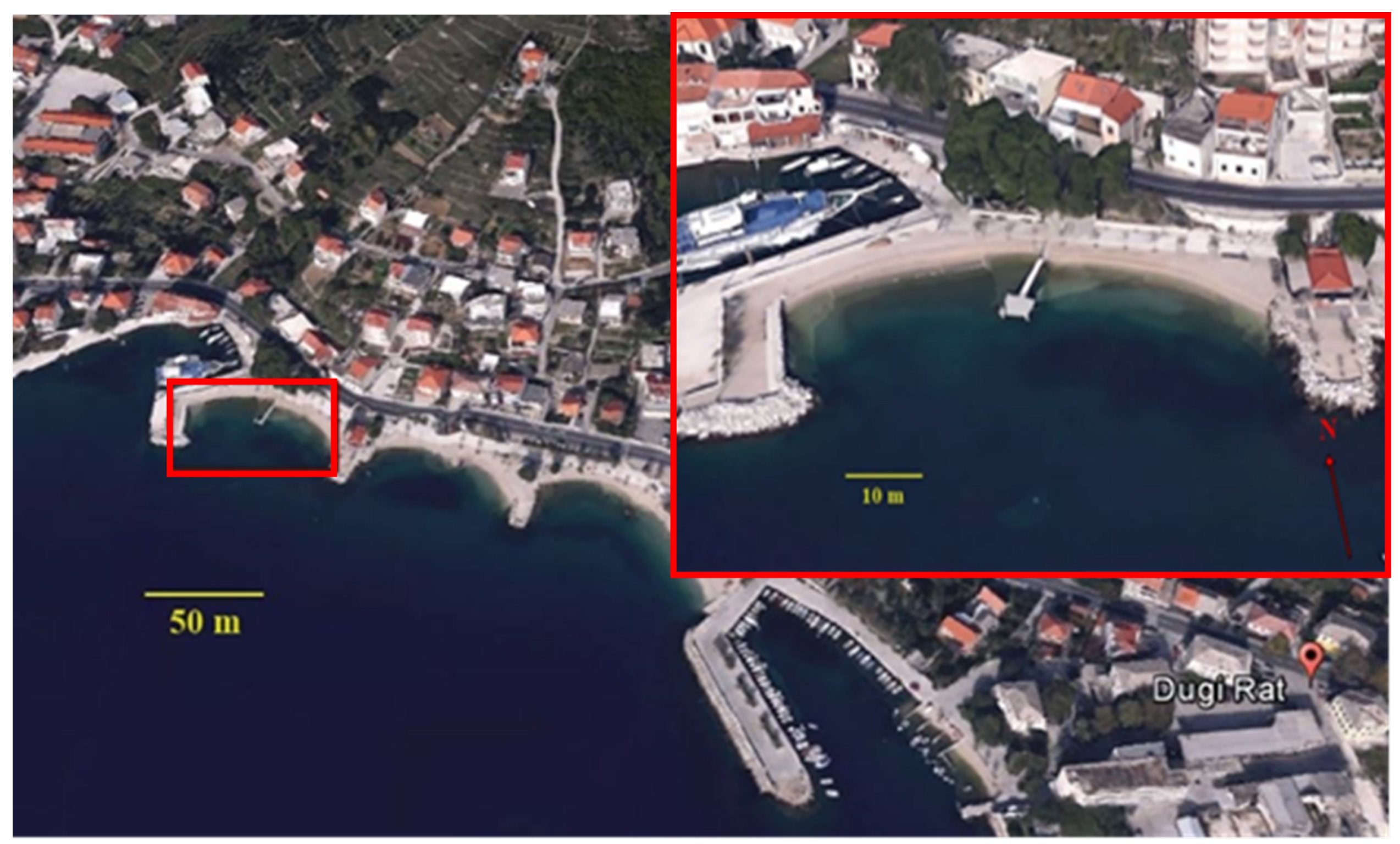




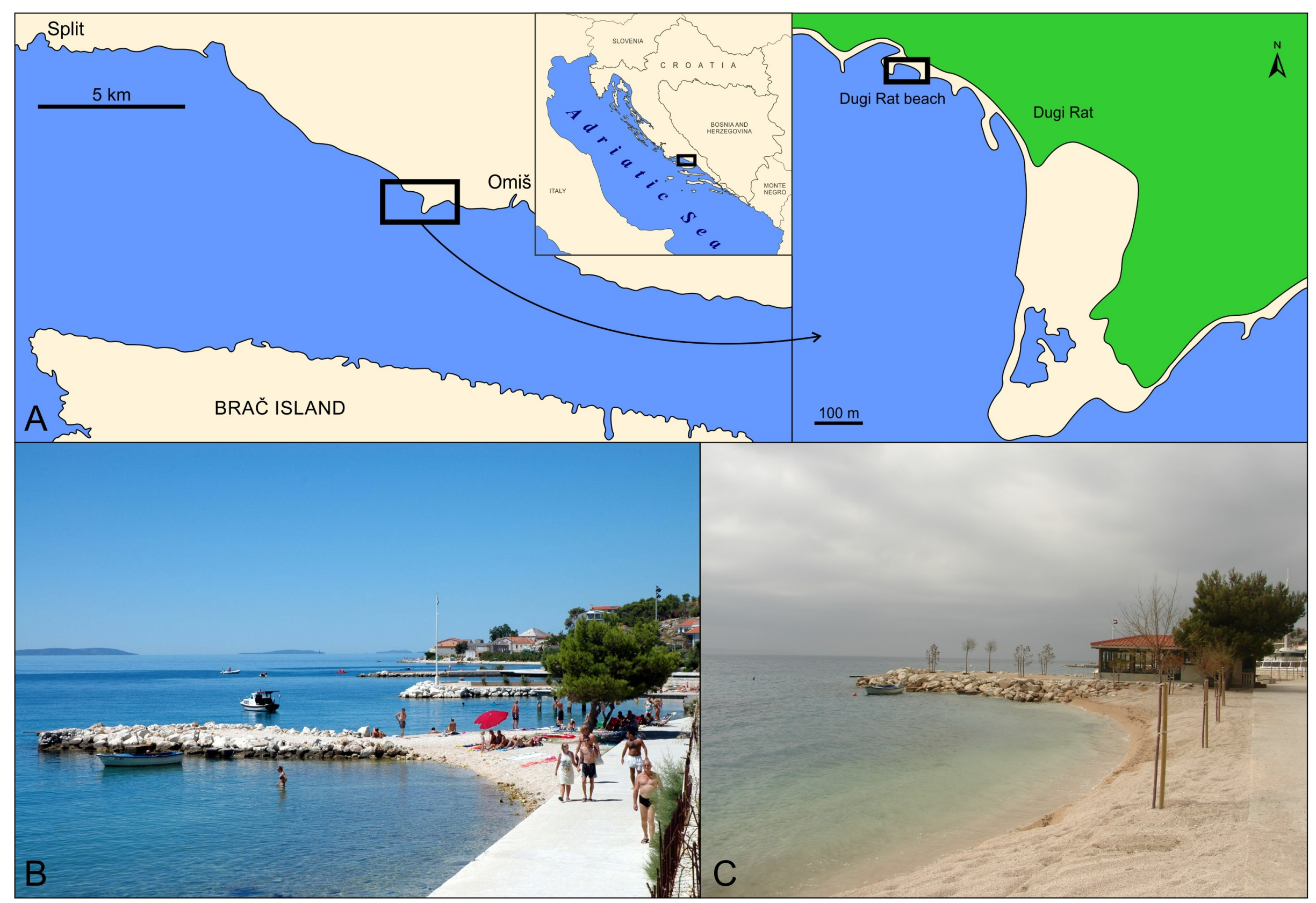




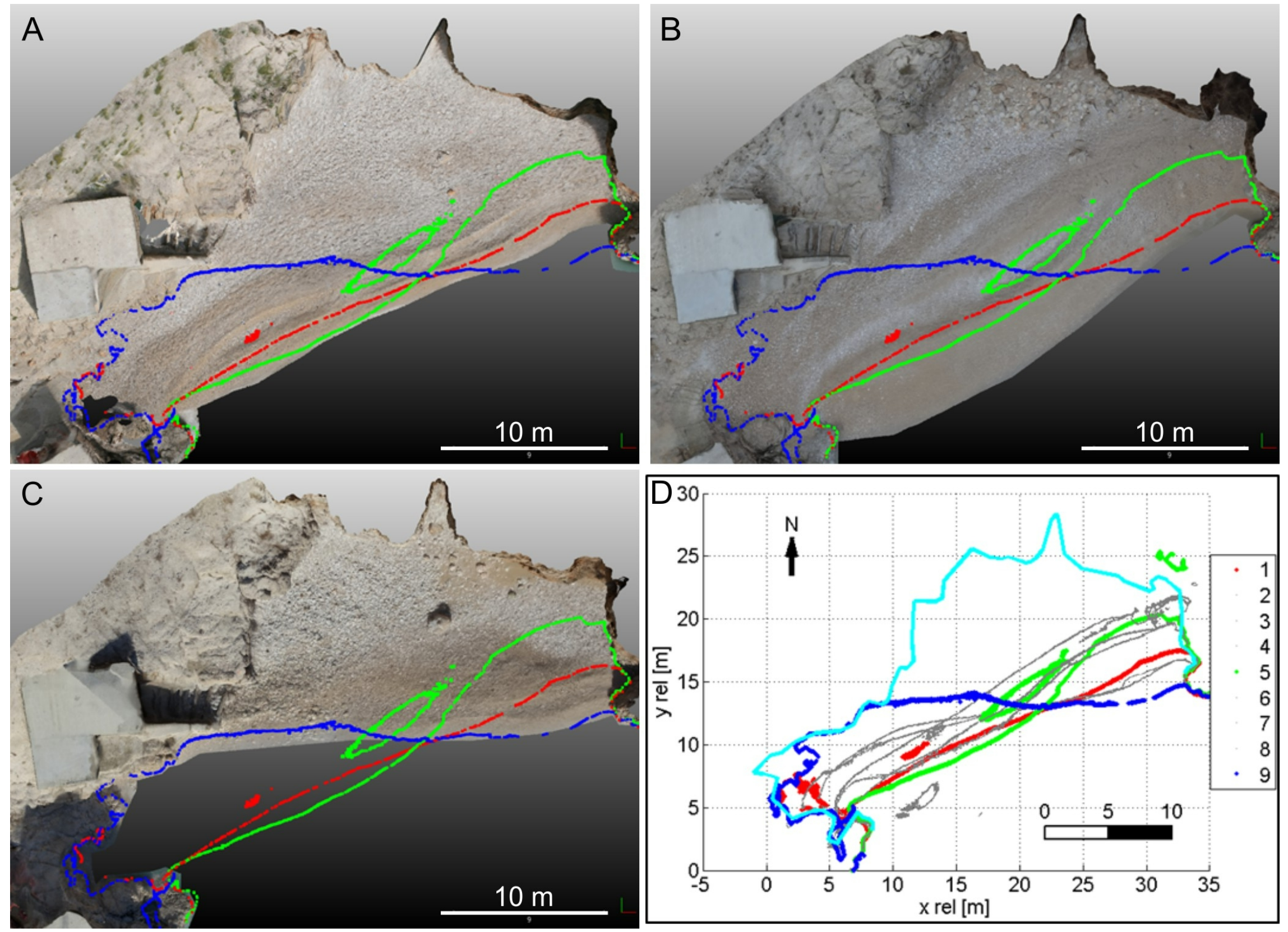




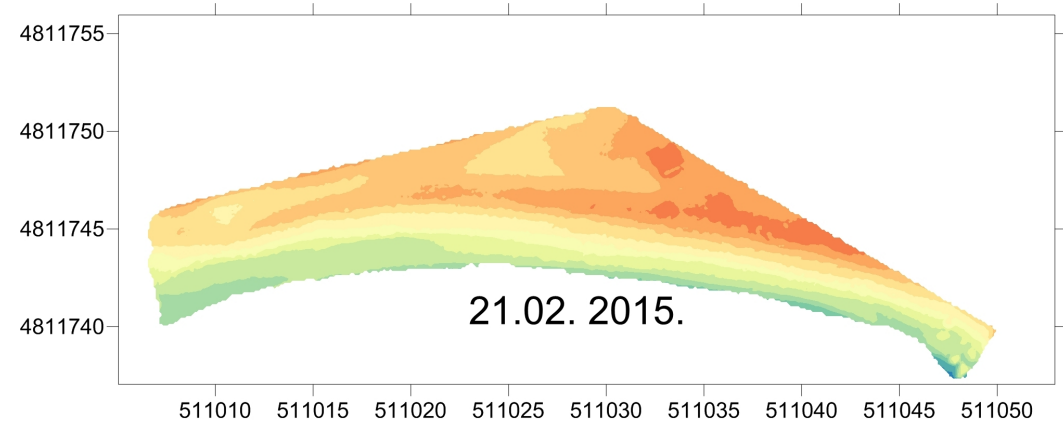

Elevation (m)
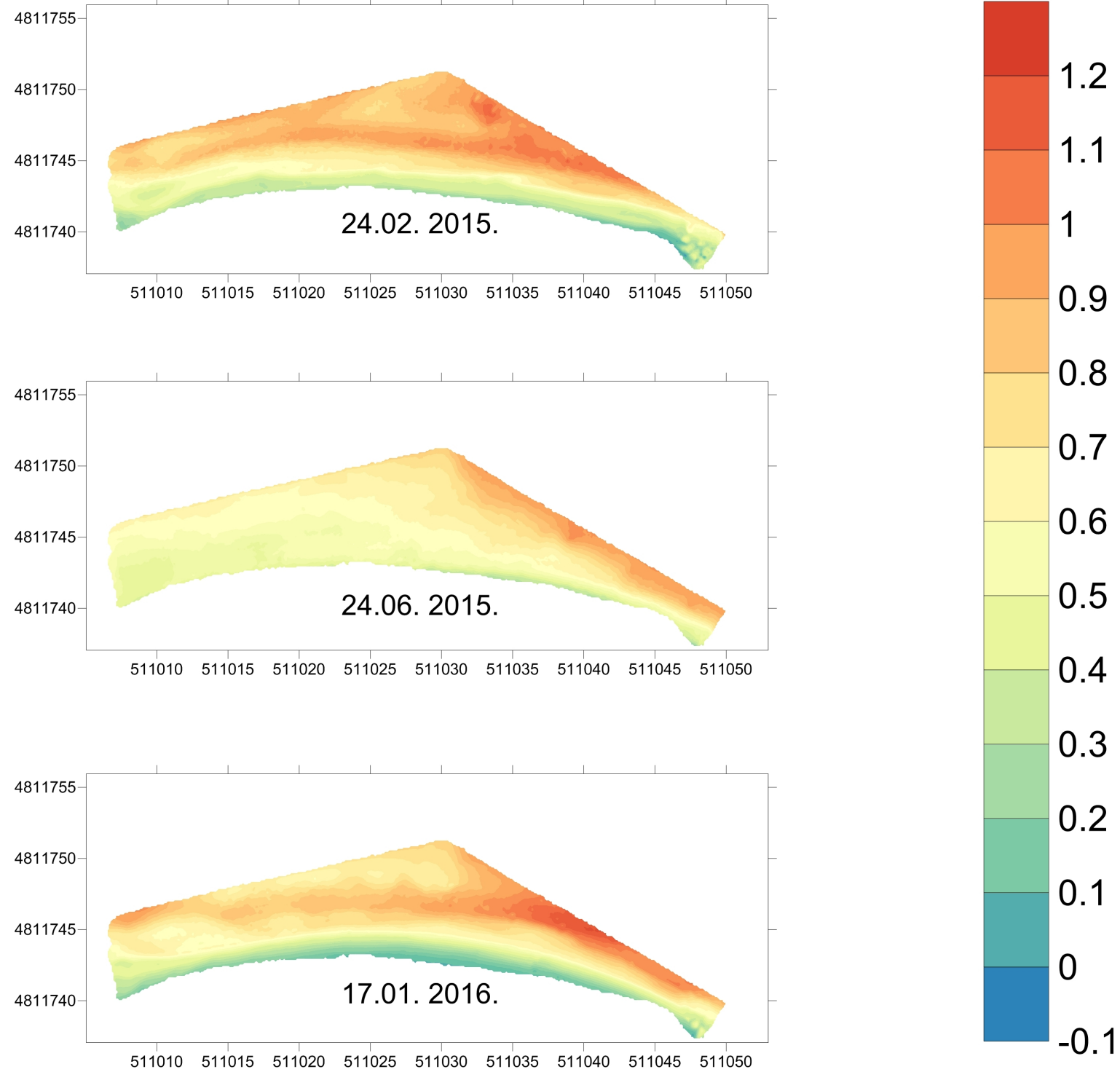

0.2
0.1
0
-0.1

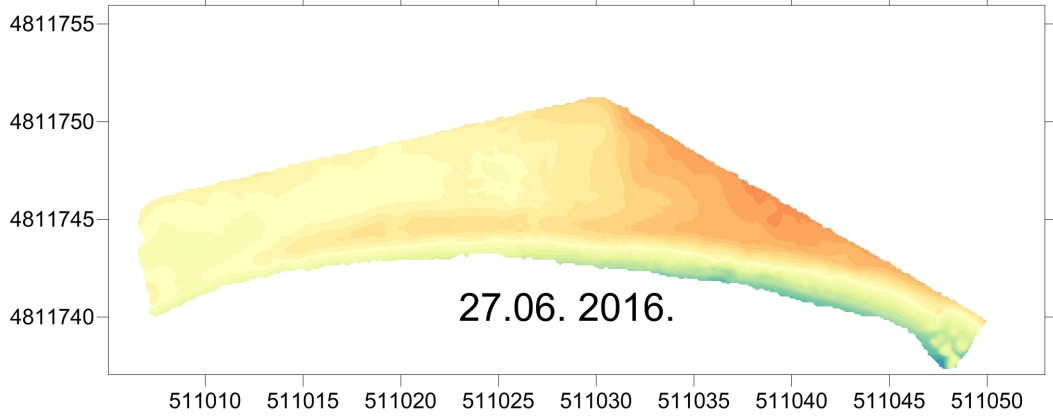



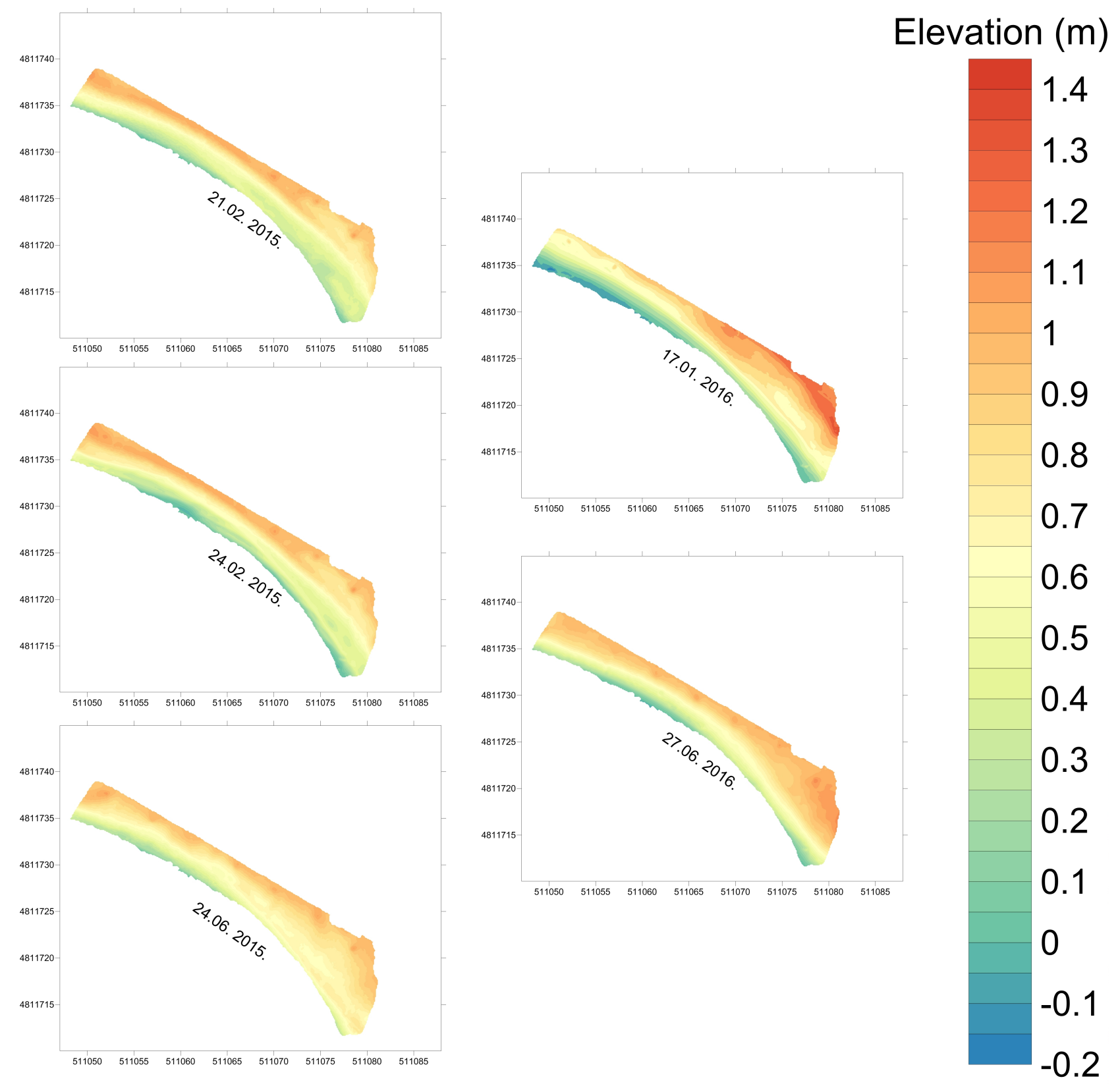


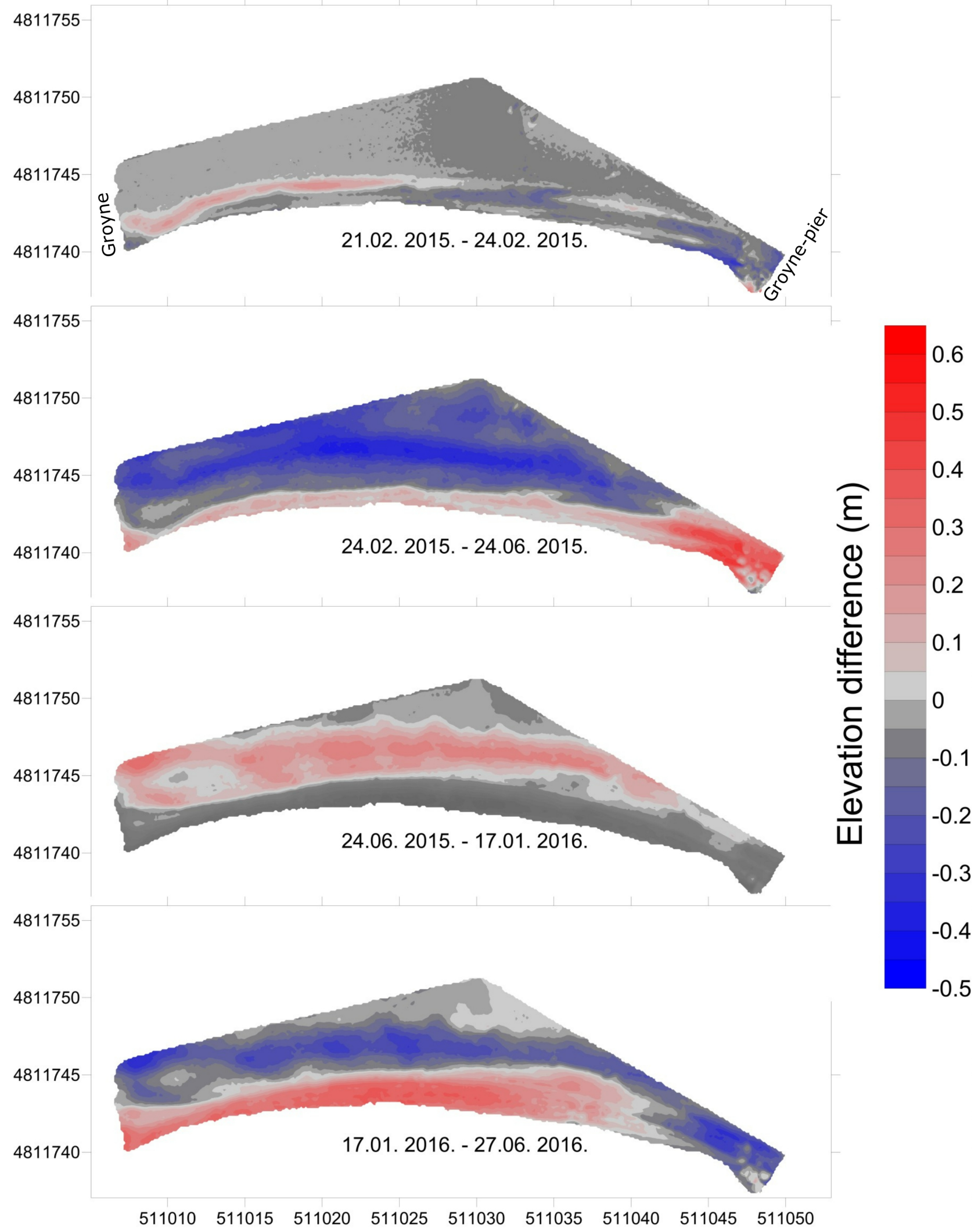



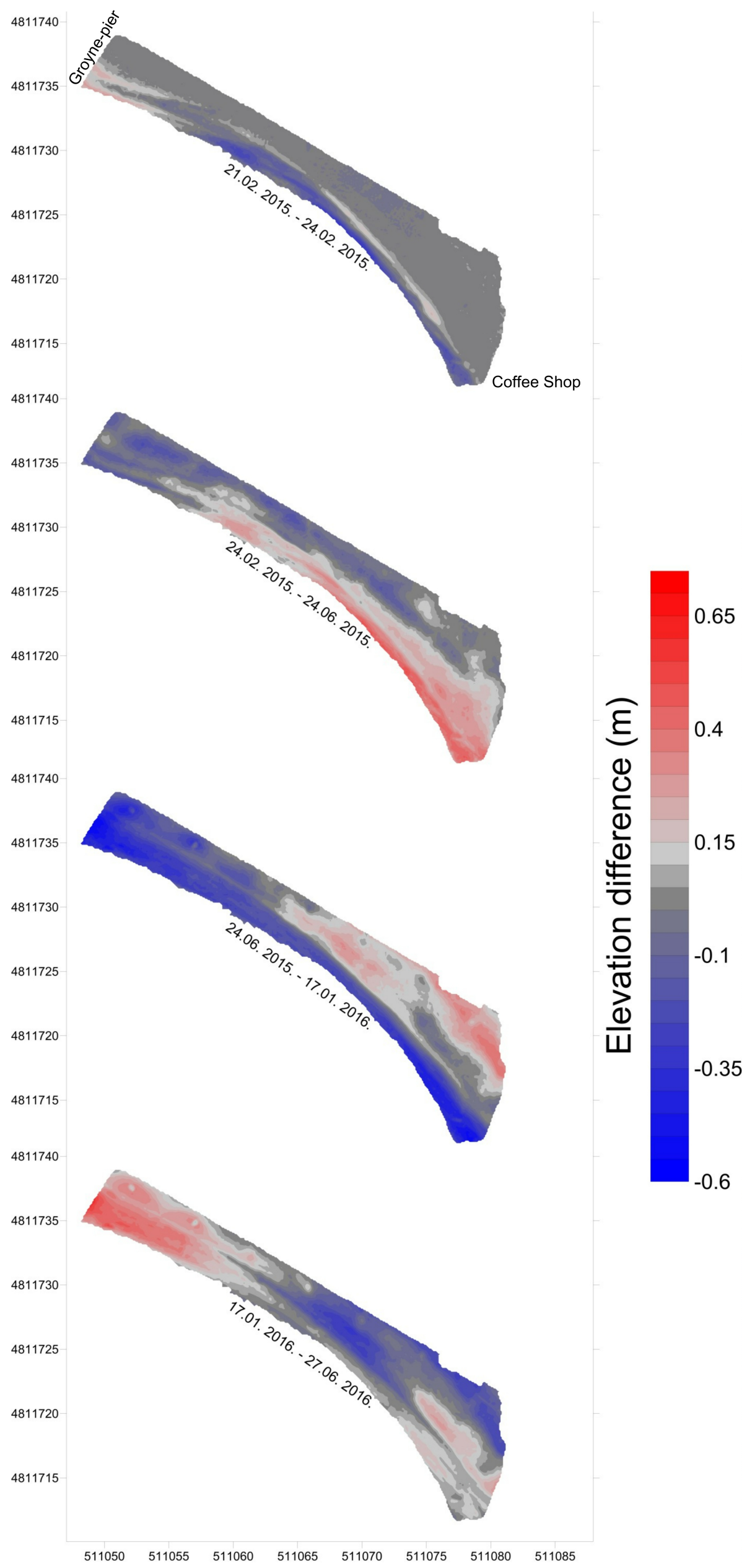


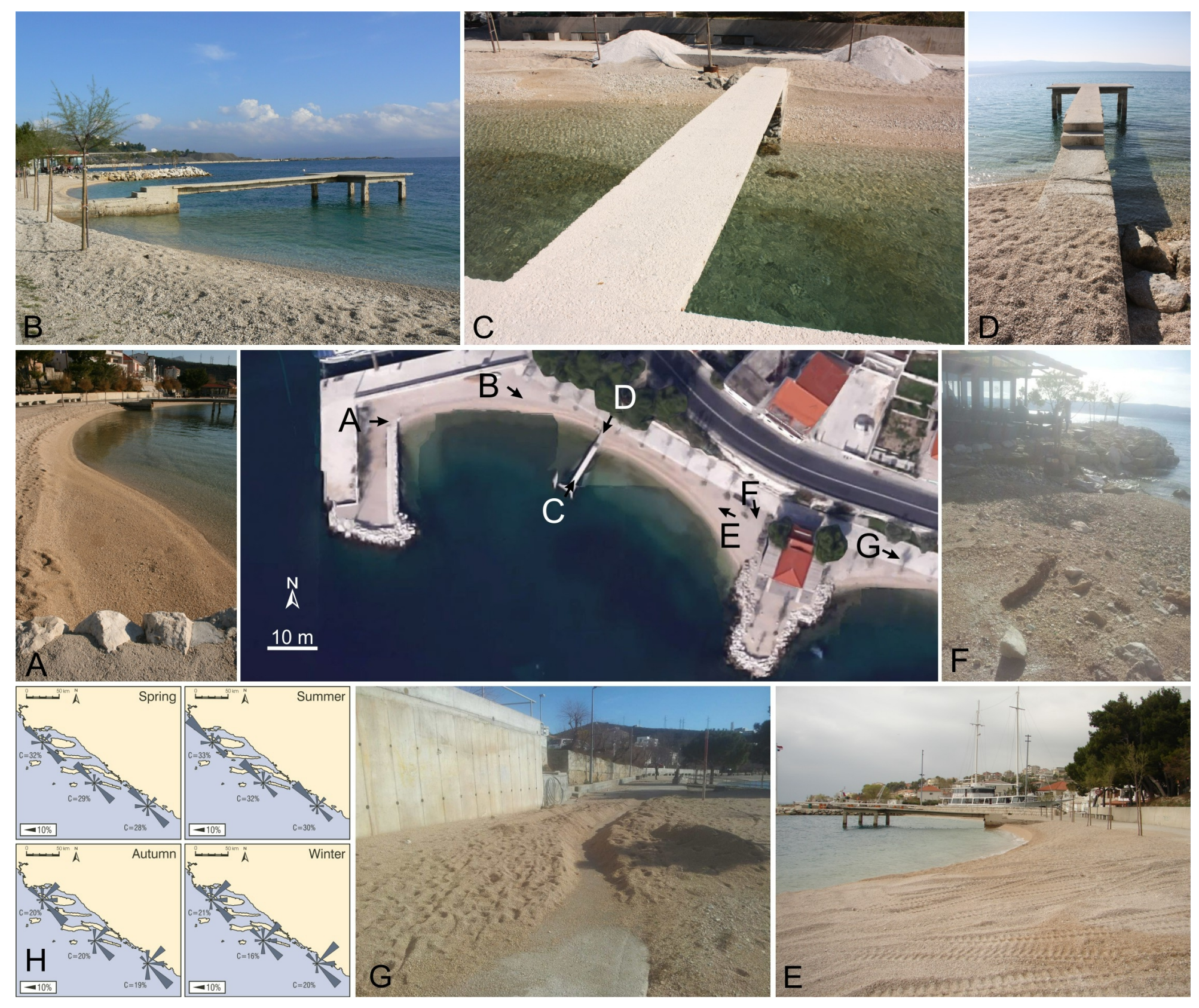


Figure 1. Simplified lithological map of the Eastern Adriatic coast with study sites locations (red dots) (modified after Pikelj and Juračić (2013) and Pikelj et al. (2013)).

Figure 2. A-Location map of the Brseč beach on the CEAC. B-View from the beach. C-View from the sea.

Figure 3. Brseč beach shoreline, land-use and coverage changes between 1968 (A) and 2011 (B). Blue line denotes surface stream. C-Matching of the average shoreline position in 2011 (red line) and 2013 surveys (gray lines) and the comparison with the presumable shoreline position in 1968.

Figure 4. Google Map view of the investigated part (in red rectangle) of the Dugi Rat artificial beach system. Enlarged view: DRN beach section is located between groyne and groyne-pier (left part of the beach), DRS beach section is located between groyne-pier and coffee shop-groyne (right part of the beach).

Figure 5. A-Location map of the Dugi Rat beach on the CEAC. B-Appearance of the beach in 2005. C-Appearance of the beach in 2012 (B and C photos show the same coffee shop-groyne located at the SE end of the southern beach section DRS).

Figure 6. Beach shoreline change showing beach rotation on the photo-realistic point cloud. All coloured lines refer to $0.4 \mathrm{~m}$ interval beach contour. A-The average (equilibrium) beach state detected during the first survey (red line). B-The first end state detected during the fifth survey after stormy NE approaching waves (green line). C-The second end state detected during the last survey after stormy SE approaching waves (blue line). D-Rotation cycle of the Brseč beach at three month time-scale. Inserted legend: representative $0.4 \mathrm{~m}$ contour of the first, fifth and the last survey are in colours (red, green and blue lines, respectively). Other surveys 0.4 contours are shown in grey.

Figure 7. From the top to bottom: DEMs of five successive morphological surveys on the DRN.

Figure 8. From the top to bottom: DEMs of five successive morphological surveys on the DRS.

Figure 9. From the top to bottom: DEMs of Differences (DoDs) of five successive morphological surveys on the DRN. Erosion is indicated in blue and deposition in red.

Figure 10. From the top to bottom: DEMs of Differences (DoDs) of five successive morphological surveys on the DRS. Erosion is indicated in blue and deposition in red. 
Figure 11. Characteristic moments in the Dugi Rat beach functioning. Central figure - Google Earth view of the studied Dugi Rat beach with positions of photographs. Directions of arrows indicate camera orientation. A-Bulge of sediment on the DRN as a result of dominated north-westward sediment transport. B-Flattened DRN section after regular nourishment. C-Appearance of the beach prior to nourishment works. D-Selective erosion around the concrete pier with sediment bypass between DRN and DRS. E-Flattened DRS section after regular nourishment. F-Heavily eroded part of the DRS section after severe Libecchio in January 2015. G-Gravel cast onto promenade after severe Libecchio in January 2015. H-Mean seasonal frequencies of wave progress directions and calms in the Central and South Dalmatia (after HHI, 2002). 
Table 1: Beach volumes changes on the Brseč beach during monitoring period in 2013, showing integrated volumes between various beach contour hights and cliff in the back. Maximum and minimum volumes are bold.

\begin{tabular}{|c|c|c|c|}
\hline \multicolumn{2}{|c|}{} & $\begin{array}{c}\text { Contour hights }(\mathrm{m}) \text { and } \\
\text { volumes }\left(\mathrm{m}^{3}\right)\end{array}$ \\
\hline $\begin{array}{c}\text { Survey } \\
\text { no. }\end{array}$ & Survey date: & $0.50 \mathrm{~m}$ & $0.75 \mathrm{~m}$ \\
\hline 1 & October 4 & 120 & 63 \\
\hline 2 & October 30 & 150 & 93 \\
\hline 3 & November 6 & $\mathbf{1 6 0}$ & $\mathbf{1 0 3}$ \\
\hline 4 & November 12 & 86 & 37 \\
\hline 5 & November 18 & 87 & 36 \\
\hline 6 & November 28 & 110 & 60 \\
\hline 7 & December 4 & 92 & 51 \\
\hline 8 & December 24 & 97 & 54 \\
\hline 9 & December 27 & $\mathbf{7 9}$ & $\mathbf{3 1}$ \\
\hline
\end{tabular}

Table 2: Beach volume changes on the Dugi Rat beach during monitoring period.

\begin{tabular}{|c|c|c|c|c|}
\hline \multicolumn{2}{|c|}{} & \multicolumn{3}{|c|}{ Beach volume $\left(\mathrm{m}^{3}\right)$} \\
\hline $\begin{array}{c}\text { Survey } \\
\text { no. }\end{array}$ & Survey date: & DRN section & DRS section & Total beach: \\
\hline 1 & February 21, 2015 & 168 & 123 & 291 \\
\hline 2 & February 24, 2015 & 170 & 124 & 294 \\
\hline 3 & June 24, 2015 & 152 & 139 & 291 \\
\hline 4 & January 17, 2016 & 159 & 129 & 288 \\
\hline 5 & June 27, 2016 & 157 & 141 & 298 \\
\hline
\end{tabular}

